\section{Algılanan Yönetici Desteği ve Algılanan Çalışma Arkadaşları Desteğinin Örgütsel Vatandaşlık Davranışı Üzerine Etkisi*}

\author{
Yildiz Tenteriz ${ }^{\mathrm{a}}$, Guler Tozkoparan ${ }^{\mathrm{b}}$
}

Öz: Bu çalışmanın amacı, algılanan yönetici desteği ve algılanan çalışma arkadaşları desteğinin örgütsel vatandaşlık davranışına etkisini incelemektir. Araştırmanın örneklemini İmir II Sağlık Müdürlüğ̈̈’nde görev yapan 325 çalışan oluşturmaktadır. Çalışmada tarama yöntemi (survey) ve anket tekniği kullanılmıştır. Araştırmada elde edilen veriler korelasyon ve çoklu doğrusal regresyon analizine tabi tutulmuştur. Araştırmada, algılanan yönetici desteği ile algılanan çalışma arkadaşları desteği bağımsız değişkenler, örgütsel vatandaşlık davranışı ise bağımlı değişken olarak ele alınmıştır. Yapılan analizlerde, algılanan yönetici desteği ile örgütsel vatandaşlık davranışı arasında anlamlı ve orta düzeyde pozitif ilişki tespit edilmiştir. Algılanan çalışma arkadaşları desteği ile örgütsel vatandaşlık davranışı arasında ise yine anlamlı ve orta düzeyde pozitif ilişki tespit edilmiştir. Elde edilen sonuçlara göre, çalışma arkadaşları desteğinin yönetici desteğine kıyasla örgütsel vatandaşlık davranışı üzerinde biraz daha fazla etkiye sahip olduğu söylenebilmektedir. Yazın taraması sırasında algılanan yönetici ve çalışma arkadaşları desteği ile örgütsel vatandaşlık davranışı ilişkisini ele alan sınırlı sayıda çalışmaya rastlanıldığından, bu yönüyle araştırmadan elde edilen sonuçların yazına ve sektöre katkı sunacağı düşünülmektedir.

\section{The Effects of Perceived Supervisor Support and Perceived Coworker Support on Organizational Citizenship Behavior}

\begin{abstract}
The purpose of this study is to determine the effect of perceived supervisor and coworker support on organizational citizenship behavior. The study sample consists of 325 employees working in Izmir Provincial Health Directorate. The survey technique, one of the quantitative research methods, was used in the study. According to the analysis results, it was determined that there is a significant and moderately positive relationship between perceived supervisor support and organizational citizenship behavior. It was concluded that there was a significant and moderately positive relationship between perceived coworker support and organizational citizenship behavior. The concepts of perceived supervisor support, coworker support, and organizational citizenship behavior constitute an important field of study in the literature. A limited number of studies have been found dealing with the relationship between supervisor and coworker perceived during the literature review and organizational citizenship behavior. This study is thought to be important due to its contributions to the literature and the organizations.
\end{abstract}

Anahtar Sözcükler: Algılanan Yönetici Desteği, Algılanan Çalışma Arkadaşları Desteği, Örgütsel Vatandaşlık Davranışı, Sağlık Kurumu

JEL: M12, M10

$\begin{array}{ll}\text { Geliş } & : \text { 14 Haziran } 2021 \\ \text { Düzeltme } & : \text { 28 Temmuz } 2021 \\ \text { Kabul } & : 03 \text { Aralık } 2021 \\ \text { Tür } & : \text { Araştırma }\end{array}$

Keywords: Perceived Supervisor Support, Perceived Coworker Support, Organizational Citizenship Behavior, Health Institution

JEL: M12, M10

Received : 14 June 2021

Revised : 28 July 2021

Accepted : 03 December 2021

Type : Research

a PhD. Student Dokuz Eylul University, Social Sciences Institute, Business Administration Department, Izmir, Turkiye, yildiztenteriz@hotmail.com (ORCID ID: 0000-0002-5717-7646)

b Assoc. Prof., PhD., Dokuz Eylul University, Faculty of Economics and Administrative Sciences, Business Administration Department, Izmir, Turkiye, g.tozkoparan@deu.edu.tr (ORCID ID: 0000-0001-9082-7092), 


\section{Giriş}

Günümüz çalışma ortamının yoğun rekabete dayalı olması sebebiyle çalışanlardan sadece biçimsel iş tanımlarında yer verilen sorumluluklarını yerine getirmelerini istemek örgütlerin devamlılı̆ını sürdürebilmesinde çoğunlukla yeterli olamamaktadır. Örgütlerin başarısında, aynı zamanda çalışanların biçimsel iş tanımlarının ötesinde ve gönüllülük temelli davranışlarda bulunmalarının da çok önemli bir rol oynadığı düşünülmektedir. Söz konusu davranışlar, yazında örgütsel vatandaşlık davranışları olarak adlandırılmaktadır (Karaman ve Aylan, 2012: 36).

Algılanan çalışma arkadaşları desteği, bir çalışanın hiyerarşide kendisiyle aynı seviyede olan benzer ya da aynı işi yapan diğer çalışanlardan algıladığı desteği ifade etmektedir (Giray, 2013: 75). Algılanan yönetici desteği kavramının ise çalışanların direkt olarak bağlı oldukları, yaptıkları işleri denetleyen ve onlardan sorumlu olan, yöneticilerinden aldıkları maddi ve manevi desteği ifade etmektedir.

Çalışanlar, örgütlerinde görevlerini yerine getirdikleri süre boyunca en çok çalışma arkadaşları ve doğrudan sorumlu oldukları yöneticileriyle zaman geçirmektedirler. Dolayısıyla çalışanların işleri ve örgütleri ile ilgili olumlu ya da olumsuz düşüncelerinin, sürekli yakın temas halinde oldukları bu kişilerin etkisiyle şekillenebileceğini söyleyebilmek mümkündür. Bu durumun ise çalışanların örgüte yönelik davranışlarını etkileyebileceği ifade edilebilmektedir.

Yazında, çalışma arkadaşları desteğinin örgüt ve işle ilgili değişkenler arasındaki ilişkisinin araştırıldığı çalışmalara pek rastlanılmamaktadır. Çalışma arkadaşları desteği kavramı çoğunlukla stres, gerginlik gibi işle ilişkili olan ancak bireylerin sağlık durumunu etkileyebilecek konuların araştırıldığı çalışmalarda görülmektedir (Giray, 2013: 76). Diğer bir destek türü olan algılanan yönetici desteğinin örgütsel vatandaşlık davranışı ile ilişkisinin ise algılanan çalışma arkadaşlarının örgütsel vatandaşlık davranışı ile ilişkisini konu alan çalışmalara kıyasla daha fazla araştırıldığı görülmektedir. Ayrıca genel olarak yazında algılanan çalışma arkadaşları desteği kavramının, yazındaki diğer kavramlarla olan ilişkisi daha az ele alınan kavramlardan biri olmuştur, özellikle örgütsel vatandaşlık davranışı ile ilişkisinin araştırıldığı çalışmalar çok sınırlıdır. Bu doğrultuda, algılanan yönetici desteğinin ve algılanan çalışma arkadaşları desteğinin örgütsel vatandaşlık davranışı üzerindeki etkisini farklı bir örneklemde incelemek amacıyla gerçekleştirilen bu çalışmanın, alan yazındaki bilgi birikimine ve sektördeki uygulamacılara yönelik katkı sunabileceği ve bu nedenle önem taşıdığı düşünülmektedir.

Belirtilen amaç ve önem doğrultusunda planlanan çalışmanın ikinci bölümünde; algılanan yönetici desteği, algılanan çalışma arkadaşları desteği ve örgütsel vatandaşık davranışı kavramları açıklanarak örgütsel vatandaşlık davranışının boyutları ve değişkenler arası ilişkiler ortaya konulmaya çalışılmışır. Üçüncü bölümde, araştırma yöntemi ile ilgili bilgilere yer verilmiştir. Dördüncü bölümde, araştırmanın bulgularına yer verilmiş ve elde edilen bulgular değerlendirilmiştir. Son bölümde ise araştırmanın genel değerlendirmesi yapılarak gelecekte konuyla ilgili çalışacak araştırmacılara yönelik önerilerde bulunulmuştur.

\section{Kavramsal Çerçeve}

\subsection{Algılanan Yönetici Desteği}

Algılanan yönetici desteği kavramı; yöneticilerin çalışanların katkılarına verdiği değerin ve çalışanlarına verdikleri önemin çalışanlar tarafından algısı olarak tanımlanmaktadır (Eisenberger vd., 2002: 567). Yöneticilerin, bir örgütte çalışanların örgütün en değerli varlığı olduğu bilinciyle, çalışanların kendilerini değerli hissedecekleri ve çalışma hayatlarının kalitesini artırmak amacıyla çalışanların her anlamda desteklenecekleri faaliyetlerde bulunmaları biçiminde de tanımlanabilmektedir (Zincirkıran, Yalçınsoy ve Işık, 2016: 977)

Çalışanlar, örgüt tarafından değerlemelerine ilişkin genel algılar oluşturmakta ve yöneticilerinin onların katkılarına ne derece değer verdiği ve onların refahını ne kadar önemsediği konusunda genel görüşler geliştirmektedirler. Yöneticiler, astların performansını yönlendirme ve değerlendirme sorumluluğuna sahip olarak örgütün temsilcileri olarak hareket ettiğinden dolayı, çalışanlar, yöneticilerinin kendilerine yönelik olumlu veya olumsuz yönelimini, aynı zamanda örgütün desteğinin göstergesi olarak görmektedirler. Ayrıca 
algılanan yönetici desteği kavramı, lider-üye değişimini içeren ilgili ölçümlerle de değerlendirilmektedir (Rhoades ve Eisenberger vd., 2002: 700).

Çalışanların ilk amirlerinden aldıkları desteği ifade eden yönetici desteği kavramı (Yoon ve Lim, 1999: 925), çalışanların "işlerini gerçekleştirmelerine yardımcı olmak için yöneticilerinin işle ilgili yardım sunmalarına olan inançları" olarak da tanımlanmaktadır (Susskind, Kacmar ve Borchgrevink, 2003: 181). Yönetici, astları tarafından destekleyici biri olarak kabul gördüğünde örgütün bütününde de aynı şekilde kabul edilmekte, mesafeli ve astlarına destek olmayan biri olarak kabul gördüğünde ise örgütün bütününde de aynı şekilde algılanmaktadır (Emhan, Mengenci, Taşdöven ve Garayev, 2014: 79). Bu durum, astlar tarafından algılanan yönetici desteğinin örgütün tamamına yansıdığını göstermesi açısından önemlidir.

Çalışanlar, yöneticilerinin destekleyici olduğuna inandıklarında, örgütlerini de kendilerine destek sağlayan bir kurum olarak görürler. Dolayısıyla yöneticiler, çalışanların örgüte olan güvenini ve bağlılıklarını etkilemede kilit bir rol oynamaktadırlar. Bu nedenle örgütler, yöneticilerini, çalışanın örgütüne yönelik olumlu tutum ve niyetler geliştirmesine yardımcı olmada etkili olabilecekleri önemli konular hakkında eğitmeyi ihmal etmemelidir (Guchait, Cho ve Meurs, 2015: 307). Yönetici desteğini hisseden ya da algılanan yönetici desteği yüksek olan çalışanlar, farklı iş imkânları olsa bile örgütten ayrılmayı düşünmemekte, böylece örgüt başarısına daha fazla katkıda bulunabilmektedirler. Bunun sonucunda çalışanlar, örgüte ilişkin kısa vadeli değil uzun vadeli planlar yapmaya başlayarak örgüte daha fazla katkıda bulunmak adına ellerinden gelen çabayı göstermek için daha çok çalışacaklardır (Ece ve Gültekin, 2018: 90). Bir çalışanın örgütüne, yöneticisine ve çalışma arkadaşlarına olan güveni ve iletişimi ne kadar fazla ise çalışma performansı da o kadar yüksek olacaktır. Bu durum ise örgütün sürdürülebilirlik, kalite, hizmet vb. konularda daha verimli çalışmasını sağlayacaktır (Akmaz ve Erbaşı, 2017: 126).

\subsection{Algılanan Çalışma Arkadaşları Desteği}

Yazında, algılanan yönetici desteği ile çalışma arkadaşları desteği, iş temelli sosyal destek kavramının içeriğini oluşturmaktadır (Yüksel, 2006: 10). Algılanan çalışma arkadaşları desteği, bir çalışanın hiyerarşik olarak kendisiyle aynı seviyede olan benzer ya da aynı işi yapan diğer çalışanlardan algıladığı destek olarak tanımlanmaktadır (Yoon ve Lim, 1999: 925; Mossholder, Settoon ve Henagan, 2005: 609; Giray, 2013: 75).

Susskind vd. (2003: 181) algılanan çalışma arkadaşları desteğini, çalışanların, işle ilgili hizmet tabanlı görevlerini yerine getirebilmelerine yardımcı olabilmek için çalışma arkadaşlarının işle ilgili yardım sağlamaya istekli olmalarına ne ölçüde inandıklarını belirttikleri bir kavram olarak tanımlamaktadırlar. Çalışma arkadaşlarının davranışları bazen rastgele olarak, başka bir deyişle planlanmamış bir biçimde bireyi etkiler. Bu nedenle çalışma arkadaşlarının etkisi çok güçlü olabilmektedir. Çalışma arkadaşları, bireye bir hedefe nasıl ulaşacağına ilişkin bilgi ve tavsiye verebilmekte, gelişimle ilgili fırsatlardan bireyi haberdar edebilmekte ve bireyin sosyal açıdan iyi ya da kötü iş davranışlarını ve çıktılarını etkileyebilmektedir (Raabe ve Beehr, 2003: 276).

Çoğu durumda, algılanan çalışma arkadaşları desteği, işle ilgili görevlerin yerine getirilmesi için hayati öneme sahiptir. Çünkü somut konulardan daha fazlasını, örneğin moral gibi konuları etkilemektedir. Çalışma arkadaşları desteği (resmi veya gayrı resmi) genellikle hiyerarşik farklılıkları içermemekte, yöneticilerden sağlanmış olan resmi desteği desteklemekte ve işin yapılmasında öngörülen örgütsel standartlara dayanmaktadır (Susskind vd., 2003: 181).

\section{3. Örgütsel Vatandaşlık Davranışı}

Örgütsel vatandaşlık davranışı (ÖVD), resmi ödül sistemi tarafından doğrudan veya açıkça tanınmayan, toplu olarak örgütün etkin işleyişini teşvik eden ve isteğe bağlı olarak gösterilen bireysel davranışlar olarak tanımlanmaktadır (Organ, 1988: 4). ÖVD; biçimsel iş tanımlarının dışında, çalışanların örgüte katkı sağlayabilmek adına gönüllü olarak gösterdikleri rol fazlası davranışlar olarak ifade edilebilmektedir (Karaman ve Aylan, 2012: 36). Böylelikle deneyimli çalışanlar, gönüllü olarak yeni çalışma arkadaşlarına işlerin nasıl yapıldığını öğretmek için örgütsel vatandaşlık davranışında bulunarak yardım 
Algılanan Yönetici Desteği ve Algılanan Çalışma Arkadaşları Desteğinin Örgütsel Vatandaşlık Davranışı Üzerine Etkisi

ettiklerinde, yeni çalışanların daha hızlı ve üretken çalışanlar olmalarına yardımcı olabilmektedirler. Böylece çalışma grubunun veya birimin verimliliği artacaktır (Podsakoff ve MacKenzie, 1997: 135).

Vatandaşlık kavramı, kişisel eğilim veya sorumluluk duygusu nedeniyle çalışanların başkalarına veya örgüte yardım etme arzusundan kaynaklanmaktadır. Söz konusu kişileri "iyi askerler" veya "iyi vatandaşlar" olarak tanımlamak bu fikri güçlendirmektedir (Bolino, 1999: 82). Bu nedenle hiç kimse izlemese bile, tüm kurallara ve düzenlemelere inanarak uyan bir çalışan, "iyi bir vatandaş" olarak kabul edilmektedir (Podsakoff, MacKenzie, Paine ve Bachrach, 2000: 517-524).

Örgüte yönelik vatandaşlık davranışları; düzeni sağlamak için tasarlanmış gayri resmi kurallara uymak, işe diğer çalışanlardan daha fazla katılım göstermek ve uzun iş molaları vermemek gibi eylemleri içermektedir. Bunun yanı sıra, diğer çalışanlara yardım etmeye odaklanan vatandaşlık davranışları, işe devam etmeyenlere veya ağır iş yükü olan meslektaşlara yardım etmek ve diğer çalışanların refahıyla kişisel olarak ilgilenmek gibi davranışları içermektedir (Turnley vd., 2003: 191).

Sabuncuoğlu ve Tüz (2005: 354)'e göre örgütsel vatandaşlık davranışı, bilinen davranış kavramının ötesinde daha ileri düzey bir görev bilincini çağrıştırmaktadır. ÖVD; örgütü, örgüte zarar verebilecek istenmeyen davranışlardan korumak, çalışanların yetenek ve hünerlerini geliştirmek, çalışan önerilerini kabul etmek, etkin ve yaygın bir iletişim ağı kurmak gibi faaliyetleri içermekte ve tüm örgüt üyelerinin de bu şekilde davranmasını gerektirmektedir. Dolayısıyla örgütsel vatandaşlık davranışı, karşılı̆ıında ücret ya da resmi ödül gibi herhangi bir talepte bulunmadan çalışanların gönüllü eylem ve karşılıklı yardım davranışında bulunmasını ifade etmekte olup, günümüzde performans analizinde yeni bir kriter haline gelmeye de başlamıştır (Lian ve Tui, 2012: 64).

Örgütsel vatandaşlık davranışları tutarlı olarak gerçekleştirildiğinde olumlu örgütsel sonuçlar artacaktır (Netemeyer, Boles, McKee ve McMurrian, 1997: 85). Örneğin; örgütteki iş başarım düzeyi, çalışanların vatandaşlık davranışı arttıkça da yükselebilecektir. Yöneticiler için çalışanların iş başarım düzeylerinin yükselmesi amaçlara ulaşılabilmede önemli bir unsur olmaktadır. Örgütsel vatandaşlık davranışı; örgütün yanında yer almayı, gerekli olduğunda örgüt için ekstra fedakârlıklarda bulunmayı ve örgütü düşünmeyi gerekli kılmaktadır. Örgütün amaçlarına ulaşması, çalışanların sorumluluk duygularının gelişmesiyle kolaylaşmaktadır. Çünkü çalışanların yetkilerini belirli bir sorumluluk çerçevesinde kullanmaları, örgüt içerisinde yöneticilerin denetimlerini kolaylaştırmakta ve bireysel özdenetimi artırabilmektedir (Özdevecioğlu, 2003: 119). Örneğin, vicdanlı bir çalışan az denetim gerektirebilmektedir. Fedakârlık ve nezaket sergileyen çalışanlar, örgüte eğitim ve kriz yönetiminde büyük ölçüde zaman ve maliyet tasarrufu sağlayabilmektedirler. Zayıf centilmenlik, yöneticilerin daha önemli işlerine yeterli zaman harcamalarını önlemekte, sivil erdem konusunda yüksek çalışanlar ise departmanlarında veya işletmelerinde yapılabilecek değişikliklere ilişkin yapıcı öneriler sunarak örgütün çeşitli maliyetlerden tasarruf etmesini sağlayabilmektedirler (VanYperen, Van den Berg ve Willering, 1999: 378).

Podsakoff ve MacKenzie (1997: 138-139)'e göre, kaynakları daha verimli amaçlar için kullanılabilecek şekilde boşaltmak, çalışma grupları içinde ve arasında faaliyetleri koordine etmeye yardımcı olmak, örgütün en iyi çalışanları çekme ve elde tutma yeteneğini güçlendirmek, örgütün performansının istikrarını artırmak, örgütsel vatandaşlık davranışııın örgüte sağlayabileceği katkılardandır. Ek olarak ÖVD, bir örgütün değişen ortamlara uyum sağlama yeteneğini çeşitli yollarla geliştirmeye yardımcı olabilmektedir. Örneğin, pazar yeri ile yakın temas halinde olan çalışanlar, çevredeki değişiklikler ile ilgili olarak örgüte bilgi vermede gönüllü olabilecek ve örgütün değişikliklere karşı nasıl bir cevap verilebileceği konusunda önerilerde bulunurlarsa o ölçüde örgütün değişime uyum sağlamasına yardımcı olacaklardır.

Çalışma kapsamında, Organ (1988)'ın sınıflandırdığı şekilde diğerkâmlık (özgecilik), vicdanlılık, centilmenlik, nezaket ve sivil erdem olmak üzere örgütsel vatandaşlık davranışının beş boyutu ele alınmıştır.

Diğerkâmlık, diğer bir ifadeyle özgecilik (altruism); çalışanın meslektaşlarına, ortaklarına, müşterilere veya patronu/yöneticisi gibi belirli kişilere yardım şeklini alan etkililiğe yapılan katkıları belirtmek için kullanılan bir kavramdır (Organ, 1997: 94). Bu davranış, yeni çalışanları yönlendirmeye yardımcı olma ve zor işlerde başkalarına yardım etme gibi, çalışanların çalışma arkadaşlarına yardım etmedeki istekliliğini 
açıklamaktadır (Ackfeldt ve Coote, 2005: 152). Vicdanlılık (conscientiousness); çalışanların kendilerinden beklenen rol davranışının dışında bir davranışı anlatmaktadır. Örneğin, çalışanların olumsuz koşullarda bile işlerine zamanında gelmeye çalışmaları bu boyut için bir örnektir (Çetin, 2004: 20). Centilmenlik ya da diğer bir ifadeyle sportmenlik (sportsmanship); çalışanların önemsiz konularda şikâyet etmemek, diğer çalışanlarda hata bulamamak gibi işyerindeki küçük aksaklıkları tolere etme istekliliğini açıklamaktadır (Ackfeldt ve Coote, 2005: 152). Nezaket (courtesy); belirli kişiler için ortaya çıkabilecek sorunları önlemek amacıyla gösterilen ÖVD davranışları olarak tanımlanmaktadır (Organ, 1997: 94). Sivil erdem ya da bir diğer ifadeyle örgütsel katılım (civic virtue); bir bütün olarak kuruluşa makro düzeyde bir ilgiyi veya bağlılığı temsil etmekte olup (Podsakoff vd., 2000: 525), gönüllü olarak toplantılara katılma, yazışmalara hemen yanıt verme gibi örgütsel faaliyetlere yapıcı katılımı kapsayan davranışları ifade etmektedir (Ackfeldt ve Coote, 2005: 152).

\subsection{Değişkenlerarası ílişkiler}

Sosyal değişim teorisi bakımından değerlendirildiğinde, çalışanların yöneticileri ile olan ilişkileri, çalışanların örgüte yönelik tutumlarını büyük ölçüde etkilemekte ve aldığı destek çalışanın davranış değişikliği göstermesine neden olmaktadır. Böylece, yöneticisi tarafından desteklenmediği algısına sahip bir çalışan örgüte katkı sağlamaktan vazgeçip örgütten uzaklaşırken, yöneticisi tarafından desteklendiğini düşünen çalışan ise örgüte katkı sunarak örgütü yaşatma davranışı içerisine girecektir (Ece ve Gültekin, 2018: 90). Sosyal değişim teorisi, çalışanların motivasyonunu anlama ve örgüt hedeflerine ulaşma ile ilişkisinin önemini vurgulamaktadır. Örgütsel davranışa bu tür yaklaşımlar, çalışanlarla işverenler arasındaki karşılıklı yükümlülükler dahilinde belirli faaliyetler yürütme konusundaki motivasyonlarını içermektedir (Aselage ve Eisenberger, 2003: 492).

Organ ve Ryan (1995), 55 çalışmayı ele aldıkları meta analiz çalışmaları sonucunda lider desteği ile ÖVD boyutlarından diğerkâmlık (özgecilik) arasında güçlü bir ilişki olduğu sonucuna ulaşmışlardır. Gençtürk (2005)'ün, 341 çalışan üzerinde gerçekleştirdiği araştırma sonucunda, iş ortamında algılanan sosyal desteğin çalışanların örgütsel vatandaşlık davranışı göstermesinde pozitif ilişkisinin olduğu sonucuna ulaşılmıştır.

Chen ve Chiu (2008), yedi işletmede 323 çalışan ve onların orta düzey yöneticileri üzerinde yaptıkları araştırma sonucunda, yönetici desteğinin çalışanların örgütsel vatandaşlık davranışı üzerinde etkisinin olduğu bulgusuna ulaşmışlardır. Chiaburu ve Harrison (2008), 77954 çalışanın verilerinin değerlendirildiği meta analiz çalışmasında, çalışma arkadaşları desteğinin bireye ve örgüte yönelik örgütsel vatandaşlık davranışı (ÖVD-B ve ÖVD-Ö) ile pozitif ilişkili olduğu sonucuna ulaşmışlardır.

Algılanan yönetici desteğinin etkisine yönelik olarak Özdemir (2010), sekiz ilköğretim okulundaki 172 öğretmen üzerinde gerçekleştirdiği araştırmasında, algılanan yönetici desteği ile öğretmenlerin ÖVD'leri arasında olumlu bir ilişki olduğu sonucuna ulaşmıştır. Liu, Cho ve Seo (2011), 257 otel çalışanından elde ettikleri verilerin analizi sonucunda, çalışanların yönetici desteği aldıkça örgütsel vatandaşlık davranışı gösterdikleri sonucuna ulaşmışlardır. Kopp (2013), 132 çalışan üzerinde gerçekleştirdiği araştırma sonucunda, çalışma arkadaşları desteği ve örgütsel vatandaşlık davranışı arasında zayıf derecede pozitif, yönetici desteği ve örgütsel vatandaşlık davranışı arasında önemli derecede pozitif ilişkinin olduğu bulgusunu elde etmiştir.

Wang (2014) ise 238 çalışan üzerinde gerçekleştirdiği araştırma sonucunda, yöneticilerinden destek aldıkça çalışanların örgütsel vatandaşlık davranışında bulunacakları bulgusunu elde etmiştir. Sultana, Rabie, Farooq ve Amjad (2016), eğitim sektöründe 586 çalışan üzerinde yaptıkları çalışmada, algılanan yönetici desteği ile örgütsel vatandaşlık davranışı arasında pozitif ve anlamlı ilişki bulmuşlardır. Akram, Kamran, Iqbal, Habibah ve Ishaq (2018)'ın, telekomünikasyon sektöründen 350 çalışan üzerinde yaptıkları araştırmada, algılanan yönetici desteği ile örgütsel vatandaşlık davranışı arasında pozitif ve anlamlı ilişki bulunmuştur.

Konuyla ilgili yürütülen çalışmalar ışığında, araştırmanın ana hipotezleri şu şekilde oluşturulmuştur:

$H_{1}$ : Algılanan yönetici desteği, örgütsel vatandaşlık davranışı üzerinde pozitif yönde etkilidir.

$\mathrm{H}_{2}$ : Algılanan çalışma arkadaşları desteği, örgütsel vatandaşlık davranışı üzerinde pozitif yönde etkilidir.

Araştırmanın alt hipotezleri ise şu şekilde oluşturulmuştur:

$H_{3}$ : Algılanan yönetici desteği, örgütsel vatandaşlık davranışının nezaket boyutu üzerinde pozitif yönde etkilidir. 
$H_{4}$ : Algılanan yönetici desteği, örgütsel vatandaşılı davranışının sivil erdem boyutu üzerinde pozitif yönde etkilidir.

$H_{5}$ : Algılanan yönetici desteği, örgütsel vatandaşlık davranışııın diğerkâmlık boyutu üzerinde pozitif yönde etkilidir.

$H_{6}$ : Algılanan yönetici desteği, örgütsel vatandaşlık davranışının vicdanlılık boyutu üzerinde pozitif yönde etkilidir.

$H_{7}$ : Algılanan yönetici desteği, örgütsel vatandaşlık davranışının centilmenlik boyutu üzerinde pozitif yönde etkilidir.

$H_{8}$ : Algılanan çalışma arkadaşları desteği, örgütsel vatandaşlık davranışının nezaket boyutu üzerinde pozitif yönde etkilidir.

$H_{g}$ : Algılanan çalışma arkadaşları desteği, örgütsel vatandaşlık davranışının sivil erdem boyutu üzerinde pozitif yönde etkilidir.

$H_{10}$ : Algılanan çalışma arkadaşları desteği, örgütsel vatandaşılı davranışının diğerkâmlık boyutu üzerinde pozitif yönde etkilidir.

$H_{11}$ : Algılanan çalışma arkadaşları desteği, örgütsel vatandaşlık davranışının vicdanlıık boyutu üzerinde pozitif yönde etkilidir.

$H_{12}$ : Algılanan çalışma arkadaşları desteği, örgütsel vatandaşlık davranışının centilmenlik boyutu üzerinde pozitif yönde etkilidir.

\section{Metodoloji}

Algılanan yönetici desteği ve algılanan çalışma arkadaşları desteği bağımsız değişkenlerinin, bağımlı değişken olan örgütsel vatandaşlık davranışına etkisini temsil eden araştırmanın modeli Şekil 1 'de görülmektedir.

Şekil 1. Araştırmanın Modeli

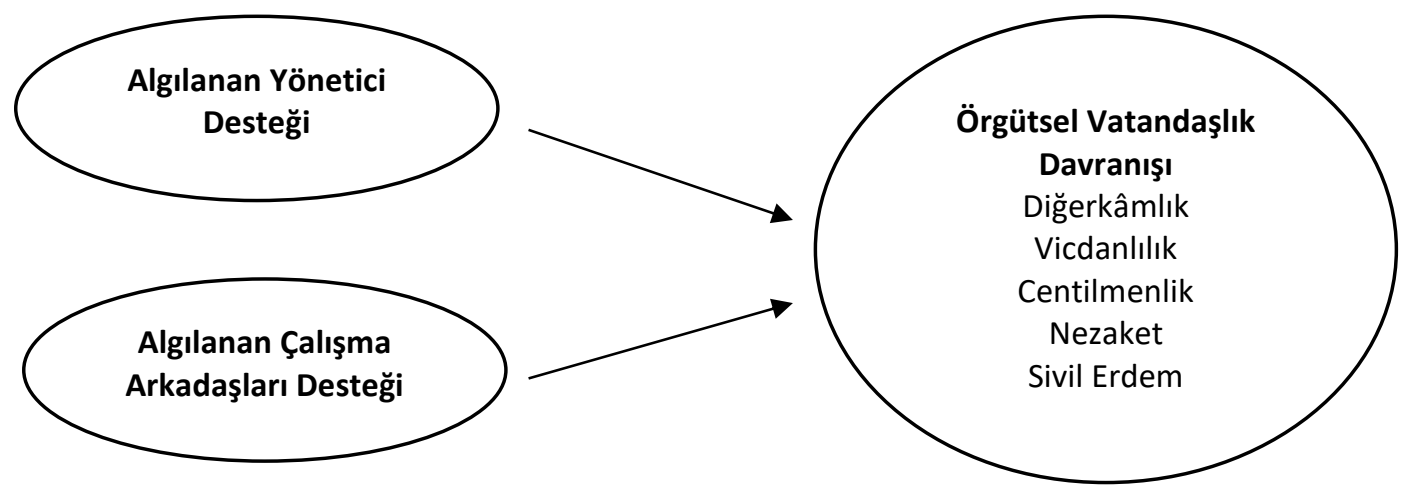

Araştırmanın evrenini İzmir îl Sağılık Müdürlüğü ve bağlı birimlerdeki tüm çalışanlar oluşturmaktadır. Basit tesadüfi örnekleme yöntemiyle 2020 Ocak ayı boyunca 400 çalışana elden dağıtılan soru formlarından 350 adedi geri dönmüş, analize uygun 325 adedi değerlendirmeye tabi tutulmuştur. Araştırma yapılan kurumun evren büyüklüğünü paylaşmaması nedeniyle örneklem sayısı için genel bir kuraldan yola çıkılmıştır. Genel kural olarak örneklem büyüklüğünün en az gözlenen değişken sayısının beş katı olması gerektiği (Büyüköztürk, 2002: 480) ifade edildiğinden hesaplamalar sonucu araştırma kapsamında örneklem için gereken ideal sayının da üzerine çıkıldığı görülmüştür. Analize dahil edilmeyen anketler, eksik doldurulması nedeniyle çalışmaya dahil edilmemiştir.

Araştırmada tarama yöntemi (survey) ile anket tekniği kullanılmıştır. Araştırmada kullanılan algılanan yönetici ve çalışma arkadaşları desteği ölçekleri, Giray ve Şahin (2012)'in çalışmalarında belirttikleri farkı ölçeklerden yararlanarak oluşturdukları örgüt, yönetici ve çalışma arkadaşları desteği ölçeklerini Türkçeye 
uyarladıkları çalışmalarından alınmıştır. Yazarlar yedi farklı algılanan yönetici desteği ölçeğinden (Karasek, Triantis ve Chaudhry, 1982; Gant, Nagda, Brabson, Jayaratne, Chess ve Singh, 1993; Babin ve Boles, 1996; Liden ve Maslyn, 1998; Yoon ve Lim, 1999; Jiang ve Klein, 2000; Gillen, Baltz, Gassel, Kirsch ve Vaccaro, 2002) ifadeler alarak birbirinin aynısı olmayan ama birbirini tamamlayıcı rol oynayan maddeler seçmişlerdir.

Çalışma arkadaşları desteği ölçeği için ise yazarlar üç farklı (Gant, Nagda, Brabson, Jayaratne, Chess ve Singh, 1993; Yoon ve Lim, 1999; Gillen, Baltz, Gassel, Kirsch ve Vaccaro, 2002) ölçekten yararlanmışlardır. Ölçek, yazarların geçerlilik ve güvenirliliğini test emek amacıyla yaptıkları çalışmada aynı şekilde farklı ölçekler birleştirilerek oluşturulmuştur. Algılanan çalışma arkadaşları desteği ölçeği de yönetici desteği ölçeğinde olduğu gibi, araştırmacılar tarafından çeşitli ölçeklerden algılanan çalışma arkadaşları desteği kavramını ölçmek amacıyla birbirini tamamlayan 9 madde seçilerek oluşturulmuştur. Sonuç olarak algılanan çalışma arkadaşları desteği ölçeği 9 maddeden, algılanan yönetici desteği ölçeği ise 11 maddeden oluşmaktadır.

Çalışanların ifadelere ne ölçüde katıldıklarını belirlemek amacıyla beşli Likert ölçeği kullanılmıştır (1: Kesinlikle Katılmıyorum, 5: Kesinlikle Katılıyorum). Algılanan yönetici desteği ölçeğinden "Yöneticim işimle ilgili sorunları dinlemeye her zaman için hazırdır." ifadesi örnek olarak verilebilir. Algılanan çalışma arkadaşı desteği ölçeğinden ise "Çalışma arkadaşlarım bir derdim olduğunda yakın ve anlayışlı davranırlar." ifadesi örnek olarak verilebilir.

Örgütsel vatandaşlık davranışını ölçmek için ise Basım ve Şeşen (2006) tarafından Türkçeye uyarlanan ve 19 maddeden oluşan örgütsel vatandaşık davranışı ölçeği kullanılmıştır. Yazarlar iki ölçekten (Williams ve Shiaw, 1999; Vey ve Campbell, 2004) yararlanmışlardır. Beş temel boyuttan oluşan ölçek, 1988 yılında Organ tarafından ortaya konulan örgütsel vatandaşlık davranışı boyutları ile uyumludur (Basım ve Şeşen, 2006: 88). Çalışanların ifadelere ne ölçüde katıldıklarını belirlemek amacıyla altılı Likert ölçeği kullanılmıştır (1: Kesinlikle Katılmıyorum, 6: Kesinlikle Katılıyorum). Örgütsel vatandaşlık davranışı ölçeğinden "Işs esnasında sorunla karşılaşan kişilere yardım etmek için gerekli zamanı ayırııım." ifadesi örnek olarak verilebilir.

Katılımcıların demografik özelliklerini belirlemek amacıyla frekans analizinden yararlanılmıştır. Ölçeklerin geçerlilik ve güvenilirliklerini tespit etmek amacıyla faktör analizi yapılmıştır. Araştırmada değişkenler arası ilişkilerin ortaya konulması amacıyla korelasyon analizi ve bağımsız değişkenler olan algılanan yönetici ve çalışma arkadaşları desteğinin bağımlı değişken olan örgütsel vatandaşlık davranışına etkisini ölçmek amacı ile regresyon analizi yapılmıştır.

\section{Araştırma Bulguları ve Bulguların Değerlendirilmesi}

Araştırma verilerinin analizinde SPSS 24.0 istatistik paket programı kullanılmıştır. Öncelikle, katılımcıların demografik özelliklerini belirlemek amacıyla frekans analizleri yapılmış ve elde edilen sonuçlar sayı ve yüzde değerleri ile birlikte Tablo 1'de sunulmuştur.

Tablo 1'de görüldüğü gibi, katılımcıların \%50,5'i lisans, \%72'si kadın, \%72'si evli, \%41,8'i 40-49 yaş aralığındadır. Katılımcıların \%26,5'inin iş yaşamındaki toplam çalışma süresi 26 yıl ve üzeri iken mevcut kurumdaki çalışma süreleri \%40,3 ile 1-5 yıl aralığındadır.

Ölçeklerin geçerlilik ve güvenilirliklerini tespit etmek amacıyla açıklayıcı faktör analizi yapılmıştır. KMO değeri, algılanan çalışma arkadaşları desteği ölçeği için 0,901 ve Bartlett testi sonucu ise $p=0,000$ düzeyinde anlamlıdır. Yapılan faktör analizi sonucunda, algılanan çalışma arkadaşları desteği ölçeğinde yer alan maddeler tek faktör altında toplanmaktadır ve bu faktörlerin toplam varyansın \%59,4'ünü açıkladığı görülmektedir. Ölçeğin, orijinal halinde olduğu gibi analiz sonucunda tek boyutlu olduğu görülmüştür.

Algılanan yönetici desteği ölçeği için KMO değeri 0,958 ve Bartlett testi sonucu ise $p=0,000$ düzeyinde anlamlıdır. Yapılan faktör analizi sonucunda, algılanan yönetici desteği ölçeğinde yer alan sorular tek faktör altında toplanmaktadır ve bu faktörler toplam varyansın \%76,3'ünü açıklamaktadır. Ölçeğin, orijinal halinde olduğu gibi analiz sonucunda tek boyutlu olduğu görülmüştür. 
Tablo 1. Katılımcıların Demografik Özellikleri

\begin{tabular}{|c|c|c|c|}
\hline Demografik Özellik & Seçenekler & Sayı & Yüzde (\%) \\
\hline \multirow{6}{*}{ Eğitim Durumu } & Lise & 45 & 13,8 \\
\hline & Ön Lisans & 39 & 12,0 \\
\hline & Lisans & 164 & 50,5 \\
\hline & Yüksek Lisans & 74 & 22,8 \\
\hline & Doktora & 3 & 0,9 \\
\hline & Toplam & 325 & 100 \\
\hline \multirow{3}{*}{ Cinsiyet } & Kadın & 234 & 72 \\
\hline & Erkek & 91 & 28 \\
\hline & Toplam & 325 & 100 \\
\hline \multirow{3}{*}{ Medeni Durum } & Bekâr & 91 & 28 \\
\hline & Evli & 234 & 72 \\
\hline & Toplam & 325 & 100 \\
\hline \multirow{6}{*}{ Yaş } & $20-29$ & 25 & 7,7 \\
\hline & $30-39$ & 119 & 36,6 \\
\hline & $40-49$ & 136 & 41,8 \\
\hline & $50-59$ & 44 & 13,5 \\
\hline & 60 ve üzeri & 1 & 0,3 \\
\hline & Toplam & 325 & 100 \\
\hline \multirow{7}{*}{ Toplam Çalışma Süresi } & $1-5 \mathrm{yll}$ & 14 & 4,3 \\
\hline & 6-10 yıl & 63 & 19,4 \\
\hline & $11-15$ yıl & 60 & 18,5 \\
\hline & $16-20 \mathrm{yll}$ & 52 & 16,0 \\
\hline & $21-25$ yıl & 50 & 15,4 \\
\hline & 26 yıl ve üzeri & 86 & 26,5 \\
\hline & Toplam & 325 & 100 \\
\hline \multirow{7}{*}{$\begin{array}{l}\text { Kurumdaki Çalışma } \\
\text { Süresi }\end{array}$} & $1-5 \mathrm{yll}$ & 131 & 40,3 \\
\hline & 6-10 yıl & 84 & 25,8 \\
\hline & $11-15$ yıl & 46 & 14,2 \\
\hline & $16-20 \mathrm{yll}$ & 34 & 10,5 \\
\hline & $21-25 \mathrm{yll}$ & 12 & 3,7 \\
\hline & 26 yıl ve üzeri & 18 & 5,5 \\
\hline & Toplam & 325 & 100 \\
\hline
\end{tabular}

Algılanan çalışma arkadaşları desteği ölçeğine uygulanan faktör analizi sonucunda ortaya çıkan faktörler ve bu faktörlerin açıklanan toplam varyansları Tablo 2' de görülmektedir.

Tablo 2. Algılanan Çalışma Arkadaşları Desteği Ölçeğinin Faktör Analizi

\begin{tabular}{|c|c|c|c|c|c|c|}
\hline \multirow{2}{*}{ 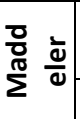 } & \multicolumn{3}{|c|}{ Başlangıç Özdeğerleri } & \multicolumn{3}{|c|}{$\begin{array}{l}\text { Karesi Alınmış Yüklemelerin Çıkartılmış } \\
\text { Toplamları }\end{array}$} \\
\hline & Toplam & Varyans \% & Kümülatif \% & Toplam & Varyans \% & Kümülatif \% \\
\hline 1 & 5,347 & 59,412 & 59,412 & 5,347 & 59,412 & 59,412 \\
\hline 2 & 0,911 & 10,127 & 69,539 & & & \\
\hline 3 & 0,730 & 8,114 & 77,653 & & & \\
\hline 4 & 0,547 & 6,074 & 83,728 & & & \\
\hline 5 & 0,469 & 5,207 & 88,934 & & & \\
\hline 6 & 0,322 & 3,575 & 92,510 & & & \\
\hline 7 & 0,309 & 3,428 & 95,938 & & & \\
\hline 8 & 0,229 & 2,547 & 98,485 & & & \\
\hline 9 & 0,136 & 1,515 & 100,000 & & & \\
\hline
\end{tabular}


Örgütsel vatandaşlık davranışı ölçeğine uygulanan faktör analizi sonucunda ortaya çıkan faktörler ve bu faktörlerin açıklanan toplam varyansları Tablo 4'te görülmektedir.

Tablo 4. Örgütsel Vatandaşlık Davranışı Ölçeğinin Faktör Analizi

\begin{tabular}{|c|c|c|c|c|c|c|c|c|c|}
\hline \multirow{2}{*}{ 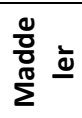 } & \multicolumn{3}{|c|}{ Başlangıç Özdeğerleri } & \multicolumn{3}{|c|}{$\begin{array}{l}\text { Karesi Alınmış Yüklemelerin } \\
\text { Çıkartılmış Toplamları }\end{array}$} & \multicolumn{3}{|c|}{$\begin{array}{l}\text { Karesi Alınmış Yüklemelerin } \\
\text { Döndürülmüş Toplamları }\end{array}$} \\
\hline & Toplam & Varyans \% & Küm. \% & Toplam & Varyans \% & Küm. \% & Toplam & Varyans\% & Küm. \% \\
\hline 1 & 6,595 & 34,712 & 34,712 & 6,595 & 34,712 & 34,712 & 4,271 & 22,477 & 22,477 \\
\hline 2 & 1,849 & 9,734 & 44,446 & 1,849 & 9,734 & 44,446 & 2,870 & 15,104 & 37,581 \\
\hline 3 & 1,524 & 8,023 & 52,468 & 1,524 & 8,023 & 52,468 & 2,455 & 12,921 & 50,502 \\
\hline 4 & 1,149 & 6,049 & 58,518 & 1,149 & 6,049 & 58,518 & 1,523 & 8,015 & 58,518 \\
\hline 5 & 0,890 & 4,684 & 63,202 & & & & & & \\
\hline 6 & 0,848 & 4,461 & 67,663 & & & & & & \\
\hline 7 & 0,778 & 4,093 & 71,756 & & & & & & \\
\hline 8 & 0,673 & 3,544 & 75,299 & & & & & & \\
\hline 9 & 0,634 & 3,336 & 78,635 & & & & & & \\
\hline 10 & 0,511 & 2,688 & 81,323 & & & & & & \\
\hline 11 & 0,486 & 2,559 & 83,882 & & & & & & \\
\hline 12 & 0,470 & 2,476 & 86,357 & & & & & & \\
\hline 13 & 0,469 & 2,470 & 88,828 & & & & & & \\
\hline 14 & 0,446 & 2,348 & 91,176 & & & & & & \\
\hline 15 & 0,402 & 2,118 & 93,294 & & & & & & \\
\hline 16 & 0,380 & 2,002 & 95,296 & & & & & & \\
\hline 17 & 0,331 & 1,742 & 97,038 & & & & & & \\
\hline 18 & 0,294 & 1,550 & 98,588 & & & & & & \\
\hline 19 & 0,268 & 1,412 & 100,00 & & & & & & \\
\hline
\end{tabular}

Örgütsel vatandaşlık davranışı ölçeği için KMO değeri 0,895 ve Bartlett testi sonucu ise $p=0,000$ düzeyinde anlamlıdır. Tablo 4'te görüldüğü üzere, yapılan faktör analizi sonucunda, örgütsel vatandaşık davranışı ölçeğinde yer alan sorular dört faktör altında toplanmaktadır ve bu faktörlerin toplam varyansın $\% 58,518$ 'ini açıkladığı görülmektedir. Toplam varyansın \%34,712'lik kısmını birinci faktör, \%9,734'lük kısmını ikinci faktör, \%8,023'lük kısmını üçüncü faktör ve \%6,049'luk kısmını ise dördüncü faktör açıklamaktadır. Faktörlere maddelerin içerikleri dikkate alınarak isim verilmiştir. Bu doğrultuda birinci faktör nezaket (10 madde); ikinci faktör sivil erdem (4 madde); üçüncü faktör diğerkamlık (özgecilik) (3 madde) ve dördüncü faktör vicdanlılık ve centilmenlik ( 2 madde) olarak adlandırılmıştır.

Tablo 5'te, örgütsel vatandaşık davranışı ölçeğinde yer alan ifadelerin hangi faktör altında toplandığına yer verilmiştir.

Ertürk (2014), araştırmasında mevcut araştırmada kullanılan 19 sorudan oluşan örgütsel vatandaşlık algısı ölçeğinden yararlanmış ve benzer olarak faktör analizi sonucunda örgütsel vatandaşlık algısı ölçeğinin anketin katılımcıları tarafından dört alt boyutta algılandığını belirlemiştir. Elde edilen dört boyut sırasıyla; centilmenlik-sivil erdem ( 7 madde), vicdanlılık-nezaket ( 6 madde), özgecilik ( 3 madde) olarak belirlenmiş ve son boyut araştırmacı tarafından profesyonellik ( 3 madde) olarak adlandırılmıştır.

Güvenilirlik analizi sonuçlarına göre, algılanan yönetici desteği ölçeği için Cronbach alpha değeri 0,969, algılanan çalışma arkadaşları desteği için 0,901, örgütsel vatandaşık davranışı ölçeği için ise 0,855 olarak tespit edilmiştir. Elde edilen sonuçlara göre, araştırmada kullanılan bütün ölçeklerin yüksek derecede güvenilir olduğu söylenebilir (Büyüköztürk, 2008: 169-170).

Değişkenler arasındaki ilişkinin tespiti için korelasyon analizi yapılmıştır. Korelasyon katsayısının büyüklük bakımından yorumlanmasında üzerinde tam olarak uzlaşılan aralıklar bulunmamakla birlikte, korelasyonu yorumlamada korelasyon katsayısının, mutlak değer olarak 0,70-1,00 arasında olması yüksek; 0,70- 0,30 arasında olması orta; 0,30-0,00 arasında olması ise düşük düzeyde bir ilişki olarak tanımlanabilir (Büyüköztürk, 2008: 32). 
Algılanan Yönetici Desteği ve Algılanan Çalışma Arkadaşları Desteğinin Örgütsel Vatandaşlık Davranışı Üzerine Etkisi

Tablo 5. Örgütsel Vatandaşık Davranışı Ölçeğinin Faktör Dağılım Tablosu

\begin{tabular}{|c|c|}
\hline Faktörler & ifadeler \\
\hline $\begin{array}{l}\text { Nezaket } \\
\text { Boyutu }\end{array}$ & $\begin{array}{l}\text { ÖVD4-işle ilgili sorunlarda elimde bulunan malzemeleri diğerleri ile paylaşmaktan } \\
\text { kaçınmam. } \\
\text { ÖVD5-İş esnasında sorunla karşılaşan kişilere yardım etmek için gerekli zamanı ayırırım. } \\
\text { ÖVD6-Zamanımın çoğunu işimle ilgili faaliyetlerle geçiririm. } \\
\text { ÖVD9-Diğer çalışanların hak ve hukukuna saygı gösteririm. } \\
\text { ÖVD10-Beklenmeyen sorunlar oluştuğunda diğer çalışanları zarar görmemeleri için } \\
\text { uyarırım. } \\
\text { ÖVD11- Birlikte görev yaptığım diğer kişiler için sorun yaratmamaya gayret ederim. } \\
\text { ÖVD12- Önemsiz sorunlar için şikâyet ederek vaktimi boşa harcamam. } \\
\text { ÖVD13- Mesai ortamı ile ilgili olarak problemlere odaklanmak yerine olayların pozitif } \\
\text { yönünü görmeye çalışırım. } \\
\text { ÖVD16-Üst yönetimce yayımlanan duyuru, mesaj, prosedür ya da kısa notları okurum ve } \\
\text { ulaşabileceğim bir yerde bulundururum. } \\
\text { ÖVD18-Şirket yapısında yapılan değişimlere ayak uydururum. }\end{array}$ \\
\hline $\begin{array}{l}\text { Sivil erdem } \\
\text { boyutu }\end{array}$ & $\begin{array}{l}\text { ÖVD7- Şirketim için olumlu imaj yaratacak tüm faaliyetlere katılmak isterim. } \\
\text { ÖVD15-Şirket içinde çıkan çatışmaların çözümlenmesinde aktif rol alırım. } \\
\text { ÖVD17-Şirketin sosyal faaliyetlerine kendi isteğimle katılırım. } \\
\text { ÖVD19-Her türlü geliştirici faaliyet icra eden araştırma ve proje gruplarının içerisinde yer } \\
\text { alırım. }\end{array}$ \\
\hline $\begin{array}{l}\text { Diğerkamlık } \\
\text { Boyutu }\end{array}$ & $\begin{array}{l}\text { ÖVD 1- Günlük izin alan bir çalışanın o günkü işlerini ben yaparım. } \\
\text { ÖVD2 -Aşırı iş yükü ile uğraşan bir şirket çalışanına yardım ederim. } \\
\text { ÖVD3-Yeni işe başlayan birisinin işi öğrenmesine yardımcı olurum. }\end{array}$ \\
\hline $\begin{array}{l}\text { Vicdanlılık } \\
\text { ve } \\
\text { Centilmenlik } \\
\text { Boyutu }\end{array}$ & $\begin{array}{l}\text { ÖVD8-Mesai içerisinde kişisel işlerim için zaman harcamam. } \\
\text { ÖVD14- Mesaide yaşadığım yeni durumlara karşı gücenme ya da kızgınlık duymam. }\end{array}$ \\
\hline
\end{tabular}

Tablo 6'da yer verilen değişkenlere ait ortalamalar incelendiğinde, algılanan çalışma arkadaşları desteğinin ortalaması 4,12'dir. Buna göre, katılımcıların çalışma arkadaşları desteği algılarının yüksek düzeyde olduğu söylenebilmektedir. Algılanan yönetici desteğinin ortalaması 3,63'tür. Dolayısıyla çalışanların yönetici desteği algılarının ortalamanın üzerinde, yükseğe yakın olduğu ifade edilebilmektedir. Örgütsel vatandaşık davranışının ortalaması ise 4,62'dir. Dolayısıyla çalışanların örgütsel vatandaşlık davranışı düzeylerinin de orta düzeyin üzerinde, yükseğe yakın olduğu söylenebilir.

Çalışanların örgütsel vatandaşlık davranışı boyutlarına ilişkin ortalamalar incelendiğinde ise en yüksek ortalamanın nezaket boyutuna $(x=4,90)$ ait olduğu görülmektedir. Bu boyutu, sivil erdem boyutu $(x=4,56)$, diğerkâmlık boyutu $(x=4,53)$, vicdanlılık ve centilmenlik boyutu $(x=4,00)$ takip etmektedir.

Tablo 6 'da yer verilen korelasyon analizi bulguları incelendiğinde, algılanan yönetici desteği ile örgütsel vatandaşlık davranışı arasında anlamlı ve orta düzeyde pozitif yönlü ilişkinin olduğu $(r=0,305, p<0,01)$ görülmüştür. Diğer bir ifade ile çalışanların yönetici desteği algısı arttıkça örgütsel vatandaşlık davranışında bulunma düzeyi de artmaktadır. Algılanan yönetici desteği ile örgütsel vatandaşlık davranışının boyutları arasındaki ilişki incelendiğinde ise nezaket boyutu ile anlamlı ve düşük düzeyde pozitif ilişki olduğu $(r=0,228$, $p<0,01)$, sivil erdem boyutu ile anlamlı ve düşük düzeyde pozitif ilişki olduğu $(r=0,281, p<0,01)$, diğerkâmlık boyutu ile anlamlı ve düşük düzeyde pozitif ilişki olduğu $(r=0,152, p<0,01)$, vicdanlılık ve centilmenlik boyutu arasında ise anlamlı ve düşük düzeyde pozitif ilişki olduğu $(r=0,214, p<0,01)$ bulunmuştur.

Korelasyon analizi sonucunda, algılanan çalışma arkadaşları desteği ile örgütsel vatandaşlık davranışı arasında anlamlı ve orta düzeyde pozitif ilişki olduğu $(r=0,361, p<0,01)$ bulgusuna ulaşılmıştır. Başka bir deyişle, çalışanların çalışma arkadaşları desteği algısı arttıkça örgütsel vatandaşlık davranışında bulunma düzeyi de artmaktadır. Algılanan çalışma arkadaşları desteği ile örgütsel vatandaşlık davranışının boyutları arasındaki ilişki incelendiğinde ise algılanan çalışma arkadaşları desteği ile örgütsel vatandaşlık davranışının nezaket boyutu arasında anlamlı ve orta düzeyde pozitif ilişki olduğu $(r=0,369, p<0,01)$, sivil erdem boyutu ile 
anlamlı ve düşük düzeyde pozitif ilişki olduğu $(r=0,203, p<0,01)$, diğerkâmlık boyutu ile anlamlı ve orta düzeyde pozitif ilişki olduğu $(r=0,337, p<0,01)$, vicdanlılık ve centilmenlik boyutu arasında ise anlamlı ve düşük düzeyde pozitif ilişki olduğu $(r=0,144, p<0,01)$ tespit edilmiştir. Tanımlayıcı istatistikler ile korelasyon analizine ilişkin sonuçlar Tablo 6'da görülmektedir.

Tablo 6. Algılanan Yönetici Desteği ve Algılanan Çalışma Arkadaşları Desteği ile Örgütsel Vatandaşlık Davranışı Boyutları Arasındaki Korelasyon Değerleri ve Tanımlayııı İstatistikler

\begin{tabular}{|c|c|c|c|c|c|c|c|}
\hline & $\begin{array}{l}\text { Nezaket } \\
\text { Boyutu }\end{array}$ & $\begin{array}{l}\text { Sivil } \\
\text { Erdem } \\
\text { Boyutu }\end{array}$ & $\begin{array}{l}\text { Diğerkamlık } \\
\text { Boyutu }\end{array}$ & $\begin{array}{c}\text { Vicdanlılık ve } \\
\text { Centilmenlik } \\
\text { Boyutu }\end{array}$ & $\begin{array}{c}\text { Algılanan } \\
\text { Çalışma } \\
\text { Arkadaşları } \\
\text { Desteği }\end{array}$ & $\begin{array}{l}\text { Algılanan } \\
\text { Yönetici } \\
\text { Desteği }\end{array}$ & $\begin{array}{c}\text { Örgütsel } \\
\text { Vatandaşlık } \\
\text { Davranışı }\end{array}$ \\
\hline $\mathbf{N}$ & 325 & 325 & 325 & 325 & 325 & 325 & 325 \\
\hline Min. & 2,20 & 1,75 & 1,00 & 1,00 & 1,33 & 1,00 & 2,05 \\
\hline Max. & 5,70 & 6,00 & 6,00 & 6,00 & 5,00 & 5,00 & 5,74 \\
\hline Ortalama & 4,907 & 4,558 & 4,529 & 4,009 & 4,119 & 3,632 & 4,617 \\
\hline Std. Sapma & 0,546 & 0,963 & 1,057 & 1,182 & 0,661 & 0,911 & 0,611 \\
\hline \multirow{3}{*}{$\begin{array}{l}\text { Nezaket } \\
\text { Boyutu }\end{array}$} & 1 & $0,557^{* *}$ & $0,511^{* *}$ & $0,308^{* *}$ & $0,381^{* *}$ & $0,208^{* *}$ & \\
\hline & & 0,000 & 0,000 & 0,000 & 0,000 & 0,000 & \\
\hline & & 325 & 325 & 325 & 325 & 325 & \\
\hline \multirow{3}{*}{$\begin{array}{l}\text { Sivil Erdem } \\
\text { Boyutu }\end{array}$} & & 1 & $0,379^{* *}$ & $0,341^{* *}$ & $0,194^{* *}$ & $0,317^{* *}$ & \\
\hline & & & 0,000 & 0,000 & 0,000 & 0,000 & \\
\hline & & & 325 & 325 & 325 & 325 & \\
\hline \multirow{3}{*}{$\begin{array}{l}\text { Diğerkamlık } \\
\text { Boyutu }\end{array}$} & & & 1 & $0,227^{* *}$ & $0,337^{* *}$ & $0,152^{* *}$ & \\
\hline & & & & 0,000 & 0,000 & 0,006 & \\
\hline & & & & 325 & 325 & 325 & \\
\hline \multirow{3}{*}{$\begin{array}{l}\text { Vicdanlılık ve } \\
\text { Centilmenlik } \\
\text { Boyutu }\end{array}$} & & & & 1 & $0,144^{* *}$ & $0,214^{* *}$ & \\
\hline & & & & & 0,009 & 0,000 & \\
\hline & & & & & 325 & 325 & \\
\hline \multirow{3}{*}{$\begin{array}{l}\text { Algılanan } \\
\text { Çalışma } \\
\text { Arkadaşları } \\
\text { Desteği } \\
\end{array}$} & & & & & 1 & $0,425^{* *}$ & $0,361^{* *}$ \\
\hline & & & & & & 0,000 & 0,000 \\
\hline & & & & & & 325 & 325 \\
\hline \multirow{3}{*}{$\begin{array}{l}\text { Algılanan } \\
\text { Yönetici } \\
\text { Desteği }\end{array}$} & & & & & & 1 & $0,305^{* *}$ \\
\hline & & & & & & & 0,000 \\
\hline & & & & & & & 325 \\
\hline
\end{tabular}

Algılanan yönetici desteğinin örgütsel vatandaşlık davranışı üzerindeki etkisini belirlemek amacıyla yapılan regresyon analizi sonuçları Tablo 7'de gösterilmektedir. Algılanan yönetici desteği bağımsız değişken olarak, örgütsel vatandaşlık davranışı ise bağımlı değişken olarak ele alınmıştır. Tablo 7'de de görüleceği üzere sabit terim 3,875, örgütsel vatandaşlık davranışına ait parametre değeri 0,205 olarak bulunmuştur. Buna göre, yönetici desteğindeki bir birimlik artış örgütsel vatandaşlık davranışını 0,205 birim artırmaktadır. Aynı zamanda model istatistiki olarak anlamlıdır $(p<0,05)$. Diğer bir ifadeyle, yönetici desteği algısındaki bir birimlik artışın örgütsel vatandaşlık davranışına olumlu yansıdığı söylenebilmektedir. Yönetici desteği algısının örgütsel vatandaşlık davranışı üzerinde düşük düzeyde de olsa bir etkisinin olduğu görülmektedir.

Tablo 7. Algılanan Yönetici Desteğinin Örgütsel Vatandaşlık Davranışına Etkisi

\begin{tabular}{|c|c|c|c|c|c|c|}
\hline \multirow{2}{*}{\multicolumn{2}{|c|}{ Model }} & \multicolumn{2}{|c|}{$\begin{array}{c}\text { Standardize Edilmemiş } \\
\text { Katsayılar }\end{array}$} & \multirow{3}{*}{$\begin{array}{c}\begin{array}{c}\text { Standartlaştırılmış } \\
\text { Katsayılar }\end{array} \\
\text { Beta } \\
\end{array}$} & \multirow{3}{*}{$\begin{array}{c}\mathrm{t} \\
29,108\end{array}$} & \multirow{3}{*}{$\begin{array}{c}p \\
0,000 \\
\end{array}$} \\
\hline & & \multirow{2}{*}{$\frac{B}{3,875}$} & \multirow{2}{*}{$\begin{array}{c}\text { Standart Hata } \\
0,133\end{array}$} & & & \\
\hline 1 & (Sabit) & & & & & \\
\hline & $\begin{array}{l}\text { Algılanan } \\
\text { Yönetici } \\
\text { Desteği }\end{array}$ & 0,205 & 0,036 & 0,305 & 5,754 & 0,000 \\
\hline \multicolumn{7}{|c|}{ a. Bağımlı Değişken: Örgütsel Vatandaşlık Davranışı } \\
\hline \multicolumn{2}{|c|}{$R=0,305$} & $\mathrm{~F}=3$ & & & & \\
\hline
\end{tabular}


Algılanan çalışma arkadaşları desteğinin örgütsel vatandaşlık davranışı üzerindeki etkisini belirlemek amacıyla yapılan regresyon analizi sonuçlarının yer aldığı Tablo 8'de görüleceği üzere, sabit terim 3,241, örgütsel vatandaşlık davranışına ait parametre değeri ise 0,334 olarak bulunmuştur. Buna göre, algılanan çalışma arkadaşları desteğindeki bir birimlik artış örgütsel vatandaşlık davranışını 0,334 birim artırmaktadır.

Analiz sonuçlarına göre, algılanan çalışma arkadaşları desteğinin örgütsel vatandaşlık davranışına ait varyansı \%13 oranında açıkladığı bulgusuna ulaşıımıştır. Başka bir deyişle, örgütsel vatandaşlık davranışındaki değişimin \%13'ü çalışma arkadaşları desteği tarafından açıklanmaktadır. Aynı zamanda model istatistiki olarak anlamlıdır $(p<0,05)$. Diğer bir ifade ile çalışma arkadaşları desteği algısındaki bir birimlik artışın örgütsel vatandaşlık davranışına olumlu yansıdığı söylenebilmektedir.

Tablo 8. Algılanan Çalışma Arkadaşları Desteğinin Örgütsel Vatandaşlık Davranışına Etkisi

\begin{tabular}{|c|c|c|c|c|c|c|}
\hline \multirow{2}{*}{\multicolumn{2}{|c|}{ Model }} & \multicolumn{2}{|c|}{$\begin{array}{c}\text { Standardize Edilmemiş } \\
\text { Katsayılar }\end{array}$} & \multirow{3}{*}{$\begin{array}{c}\text { Standartlaştırılmış } \\
\text { Katsayılar } \\
\text { Beta } \\
\end{array}$} & \multirow{3}{*}{$\begin{array}{c}\mathrm{t} \\
16,196 \\
\end{array}$} & \multirow{3}{*}{$\begin{array}{c}p \\
0,000 \\
\end{array}$} \\
\hline & & \multirow{2}{*}{$\begin{array}{c}B \\
3,241 \\
\end{array}$} & \multirow{2}{*}{$\begin{array}{c}\text { Standart Hata } \\
0,200 \\
\end{array}$} & & & \\
\hline 1 & (Sabit) & & & & & \\
\hline & $\begin{array}{l}\text { Algılanan } \\
\text { Çalışma } \\
\text { Arkadaşları } \\
\text { Desteği }\end{array}$ & 0,334 & 0,048 & 0,361 & 6,966 & 0,000 \\
\hline \multicolumn{7}{|c|}{ a. Bağımlı Değişken: Örgütsel Vatandaşlık Davra } \\
\hline \multicolumn{7}{|c|}{$R=0,361 \quad R^{2}=0,131$} \\
\hline
\end{tabular}

Elde edilen sonuçlara göre, araştırmanın birinci hipotezi olan " $\mathrm{H}_{1}$ : Algılanan yönetici desteği, örgütsel vatandaşlık davranışı üzerinde pozitif yönde etkilidir." hipotezi ile " $\mathrm{H}_{2}$ : Algılanan çalışma arkadaşları desteği, örgütsel vatandaşlık davranışı üzerinde pozitif yönde etkilidir." hipotezleri kabul edilmiştir.

Algılanan yönetici desteği ve algılanan çalışma arkadaşları desteğinin örgütsel vatandaşlık davranışı boyutları üzerindeki etkisini belirlemek üzere çoklu regresyon analizi yapılmıştır. Analizden önce, regresyon analizi için gerekli bileşenlerin sağlandığının kontrolleri yapılmış, bu kapsamda verilerin normal dağılıp dağılmadığı test edilmiş ve çarpıklık (skewness) ve basıklık (kurtosis) testi yapılmıştır. Analiz sonucunda algılanan yönetici desteğine ait çarpıklık ve basıklık değerleri $+1,5-1,5$ aralığında olup Tabachnick ve Fidell (2013)'e göre verilerin normal dağıldığı sonucuna ulaşılmıştır. Algılanan çalışma arkadaşları ve örgütsel vatandaşıık davranışına ait çarpıklık ve basıklık değerleri ise $+1,0-1,0$ aralığında olup Hair vd. (2013) çalışmasına göre verilerin normal dağıldığı sonucuna ulaşılmıştır.

Algılanan yönetici desteği ve algılanan çalışma arkadaşları desteği bağımsız değişkenler olarak ele alınırken ÖVD boyutları bağımlı değişken olarak ele alınmıştır. Analiz sonuçları Tablo 9, 10, 11 ve 12' de yer almaktadır.

Tablo 9'da görüleceği üzere, algılanan çalışma arkadaşları desteğinin örgütsel vatandaşlık davranışının nezaket boyutuna ait varyansı \%14,2 oranında açıkladığı tespit edilmiştir. Başka bir deyişle, örgütsel vatandaşlık davranışının nezaket boyutundaki değişimin \%14,2'si algılanan çalışma arkadaşları desteği tarafından açıklanmaktadır. Algılanan yönetici desteğinin ise ÖVD nezaket boyutu üzerinde anlamlı bir etkisinin olmadığı görülmektedir $(p>0,05)$. 
Tablo 9. Algılanan Yönetici Desteği ve Algılanan Çalışma Arkadaşları Desteğinin ÖVD Nezaket Boyutuna Etkisi

\begin{tabular}{|c|c|c|c|c|c|c|}
\hline \multirow{2}{*}{\multicolumn{2}{|c|}{ Model }} & \multicolumn{2}{|c|}{$\begin{array}{c}\text { Standardize Edilmemiş } \\
\text { Katsayılar }\end{array}$} & \multirow{3}{*}{$\begin{array}{c}\begin{array}{c}\text { Standartlaştırılmış } \\
\text { Katsayılar }\end{array} \\
\text { Beta } \\
\end{array}$} & \multirow{3}{*}{$\begin{array}{c}\mathrm{t} \\
19,670\end{array}$} & \multirow{3}{*}{$\begin{array}{c}p \\
0,000\end{array}$} \\
\hline & & B & Standart Hata & & & \\
\hline \multirow[t]{3}{*}{1} & (Sabit) & 3,589 & 0,182 & & & \\
\hline & $\begin{array}{l}\text { Algılanan } \\
\text { Çalışma } \\
\text { Arkadaşları } \\
\text { Desteği }\end{array}$ & 0,274 & 0,047 & 0,332 & 5,825 & 0,000 \\
\hline & $\begin{array}{l}\text { Algılanan } \\
\text { Yönetici } \\
\text { Desteği }\end{array}$ & 0,052 & 0,034 & 0,087 & 1,525 & 0,128 \\
\hline \multicolumn{7}{|c|}{ a. Bağımlı Değişken: Nezaket Boyutu } \\
\hline \multicolumn{2}{|c|}{$R=0,377$} & & 26,749 & & & \\
\hline
\end{tabular}

Tablo 10 incelendiğinde, algılanan çalışma arkadaşları desteğinin ÖVD sivil erdem boyutu üzerinde anlamlı bir etkisinin olmadığı görülmektedir $(p>0,05)$. Algılanan yönetici desteğinin ise ÖVD sivil erdem boyutu üzerinde anlamlı ve pozitif bir etkisinin olduğu görülmektedir $(p<0,05)$.

Elde edilen sonuçlardan, algılanan yönetici desteğinin örgütsel vatandaşlık davranışının sivil erdem boyutuna ait varyansı \%8,7 oranında açıkladığı tespit edilmiştir. Başka bir deyişle, örgütsel vatandaşık davranışının sivil erdem boyutundaki değişimin \%8,7'si algılanan yönetici desteği tarafından açıklanmaktadır.

Tablo 10. Algılanan Yönetici Desteği ve Algılanan Çalışma Arkadaşları Desteğinin ÖVD Sivil Erdem Boyutuna Etkisi

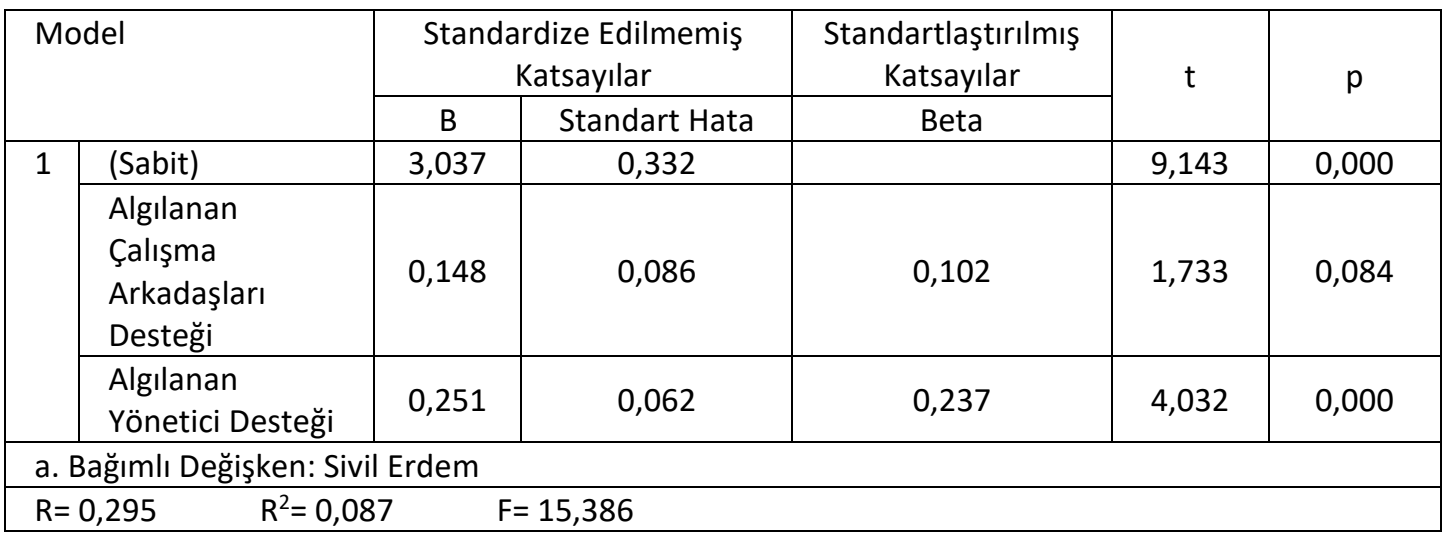

Tablo 11 incelendiğinde, algılanan yönetici desteğinin ÖVD diğerkâmlık boyutu üzerinde anlamlı bir etkisinin olmadığı görülmektedir $(p>0,05)$. Algılanan çalışma arkadaşları desteğinin ise ÖVD diğerkâmlık boyutu üzerinde anlamlı ve pozitif bir etkisinin olduğu görülmektedir $(p<0,05)$. Elde edilen sonuçlardan, algılanan çalışma arkadaşları desteğinin örgütsel vatandaşlık davranışının diğerkâmlık boyutuna ait varyansı $\% 11,3$ oranında açıkladığı tespit edilmiştir. 
Tablo 11. Algılanan Yönetici Desteği ve Algılanan Çalışma Arkadaşları Desteğinin ÖVD Diğerkâmlık Boyutuna Etkisi

\begin{tabular}{|c|c|c|c|c|c|c|}
\hline \multirow{2}{*}{\multicolumn{2}{|c|}{ Model }} & \multicolumn{2}{|c|}{$\begin{array}{c}\text { Standardize Edilmemiş } \\
\text { Katsayılar }\end{array}$} & \multirow{3}{*}{$\begin{array}{c}\begin{array}{c}\text { Standartlaştırılmış } \\
\text { Katsayılar }\end{array} \\
\text { Beta } \\
\end{array}$} & \multirow{3}{*}{$\begin{array}{c}\mathrm{t} \\
6,387\end{array}$} & \multirow{3}{*}{$\begin{array}{c}p \\
0,000\end{array}$} \\
\hline & & $B$ & Standart Hata & & & \\
\hline \multirow[t]{3}{*}{1} & (Sabit) & 2,297 & 0,360 & & & \\
\hline & $\begin{array}{l}\text { Algılanan } \\
\text { Yönetici } \\
\text { Desteği }\end{array}$ & 0,012 & 0,067 & 0,010 & 0,178 & 0,859 \\
\hline & $\begin{array}{l}\text { Algılanan } \\
\text { Çalışma } \\
\text { Arkadaşları } \\
\text { Desteği }\end{array}$ & 0,531 & 0,093 & 0,332 & 5,730 & 0,000 \\
\hline \multicolumn{7}{|c|}{ a. Bağımlı Değişken: Diğerkamlık Boyutu } \\
\hline \multicolumn{2}{|c|}{$R=0,337$} & 113 & $F=20,590$ & & & \\
\hline
\end{tabular}

Tablo 12 incelendiğinde, algılanan yönetici desteğinin ÖVD vicdanlılık ve centilmenlik boyutu üzerinde anlamlı ve pozitif etkisinin olduğu görülmektedir $(p<0,05)$. Algılanan çalışma arkadaşları desteğinin ise ÖVD vicdanlılık ve centilmenlik boyutu üzerinde anlamlı bir etkisinin olmadığı görülmektedir $(p>0,05)$. Elde edilen sonuçlardan, algılanan yönetici desteğinin örgütsel vatandaşlık davranışının vicdanlılık ve centilmenlik boyutuna ait varyansı $\% 5$ oranında açıkladığı tespit edilmiştir.

Tablo 12. Algılanan Yönetici Desteği ve Algılanan Çalışma Arkadaşları Desteğinin ÖVD Vicdanlılık ve Centilmenlik Boyutuna Etkisi

\begin{tabular}{|c|c|c|c|c|c|c|}
\hline \multirow{2}{*}{\multicolumn{2}{|c|}{ Model }} & \multicolumn{2}{|c|}{$\begin{array}{c}\text { Standardize Edilmemiş } \\
\text { Katsayılar }\end{array}$} & \multirow{3}{*}{$\begin{array}{c}\text { Standartlaştırılmış } \\
\text { Katsayılar } \\
\text { Beta } \\
\end{array}$} & \multirow{3}{*}{$\begin{array}{c}\mathrm{t} \\
6,375\end{array}$} & \multirow{3}{*}{$\begin{array}{c}p \\
0,000\end{array}$} \\
\hline & & B & Standart Hata & & & \\
\hline \multirow[t]{3}{*}{1} & (Sabit) & 2,654 & 0,416 & & & \\
\hline & $\begin{array}{l}\text { Algılanan } \\
\text { Yönetici } \\
\text { Desteği }\end{array}$ & 0,243 & 0,078 & 0,187 & 3,116 & 0,002 \\
\hline & $\begin{array}{l}\text { Algılanan } \\
\text { Çalışma } \\
\text { Arkadaşları } \\
\text { Desteği }\end{array}$ & 0,115 & 0,107 & 0,064 & 1,070 & 0,285 \\
\hline \multicolumn{7}{|c|}{ a. Bağımlı Değişken: Vicdanlılık ve Centilmenlik Boyutu } \\
\hline \multicolumn{7}{|c|}{$R=0,222 \quad R^{2}=0,049$} \\
\hline
\end{tabular}

Faktör analizi sonucunda, vicdanlılık ve centilmenlik boyutlarının tek boyut olarak toplandığı belirtilmişti. Bu nedenle $\mathrm{H}_{6}$ ve $\mathrm{H}_{7}$ hipotezleri birleştirilerek yeni hipotez "Algılanan yönetici desteği, örgütsel vatandaşlık davranışının vicdanlıık ve centilmenlik boyutu üzerinde pozitif yönde etkilidir." şeklinde oluşturulmuştur. Benzer şekilde $\mathrm{H}_{11}$ ve $\mathrm{H}_{12}$ hipotezleri de birleştirilerek yeni hipotez "Algılanan çalışma arkadaşları desteği, örgütsel vatandaşlık davranışının vicdanlıık ve centilmenlik boyutu üzerinde pozitif yönde etkilidir." şeklinde oluşturulmuştur. İki alt hipotez birleştirildiği için araştırma hipotezleri iki temel hipotez ve sekiz alt hipotez olmak üzere toplamda on hipotez olarak revize edilmiştir.

Algılanan yönetici desteği ve algılanan çalışma arkadaşları desteğinin ÖVD boyutları üzerindeki etkisine ilişkin yapılan çoklu regresyon analizleri sonucunda, algılanan çalışma arkadaşları desteğinin ÖVD'nin nezaket ve diğerkâmlık boyutu, yönetici desteğinin ise ÖVD’nin sivil erdem ile vicdanlılık ve centilmenlik boyutu üzerinde anlamlı ve pozitif bir etkisinin olduğu görülmektedir.

Tablo 13'te iki temel hipotez ve sekiz alt hipotez olmak üzere hipotez test sonuçları yer almaktadır. 
Tablo 13. Hipotez Testi Sonuçları

\begin{tabular}{|l|l|}
\hline Hipotezler & Sonuç \\
\hline $\begin{array}{l}\mathrm{H}_{1} \text { : Algılanan yönetici desteği, örgütsel vatandaşlık davranışı üzerinde pozitif yönde } \\
\text { etkilidir. }\end{array}$ & Kabul edilmiştir. \\
\hline $\begin{array}{l}\mathrm{H}_{2} \text { : Algılanan çalışma arkadaşları desteği, örgütsel vatandaşlık davranışı üzerinde } \\
\text { pozitif yönde etkilidir. }\end{array}$ & Kabul edilmiştir. \\
\hline $\begin{array}{l}\mathrm{H}_{3}: \text { Algılanan yönetici desteği, örgütsel vatandaşlık davranışının nezaket boyutu } \\
\text { üzerinde pozitif yönde etkilidir. }\end{array}$ & Kabul edilmemiştir. \\
\hline $\begin{array}{l}\mathrm{H}_{4}: \text { Algılanan yönetici desteği, örgütsel vatandaşlık davranışının sivil erdem boyutu } \\
\text { üzerinde pozitif yönde etkilidir. }\end{array}$ & Kabul edilmiştir. \\
\hline $\begin{array}{l}\mathrm{H}_{5}: \text { Algılanan yönetici desteği, örgütsel vatandaşlık davranışının diğerkâmlık boyutu } \\
\text { üzerinde pozitif yönde etkilidir. }\end{array}$ & Kabul edilmemiştir. \\
\hline $\begin{array}{l}\mathrm{H}_{6}: \text { Algılanan yönetici desteği, örgütsel vatandaşlık davranışının vicdanlılık ve } \\
\text { centilmenlik boyutu üzerinde pozitif yönde etkilidir. }\end{array}$ & Kabul edilmiştir. \\
\hline $\begin{array}{l}\mathrm{H}_{7}: \text { Algılanan çalışma arkadaşları desteği, örgütsel vatandaşlık davranışının nezaket } \\
\text { boyutu üzerinde pozitif yönde etkilidir. }\end{array}$ & Kabul edilmiştir. \\
\hline $\begin{array}{l}\mathrm{H}_{8}: \text { Algılanan çalışma arkadaşları desteği, örgütsel vatandaşlık davranışının sivil } \\
\text { erdem boyutu üzerinde pozitif yönde etkilidir. }\end{array}$ & Kabul edilmemiştir. \\
\hline $\begin{array}{l}\mathrm{H}_{9}: \text { Algılanan çalışma arkadaşları desteği, örgütsel vatandaşlık davranışının } \\
\text { diğerkâmlık boyutu üzerinde pozitif yönde etkilidir. }\end{array}$ & Kabul edilmiştir. \\
\hline $\begin{array}{l}\mathrm{H}_{10}: \text { Algılanan çalışma arkadaşları desteği, örgütsel vatandaşlık davranışının } \\
\text { vicdanlılık ve centilmenlik boyutu üzerinde pozitif yönde etkilidir. }\end{array}$ & Kabul edilmemiştir. \\
\hline
\end{tabular}

\section{Sonuç}

Örgütlerde yöneticileri tarafından desteklenen çalışanlar, örgüt ile duygusal bağlar geliştirmeye, örgütü ailesi gibi görmeye başlarlar. Yönetici desteği algılayan çalışanlar zamanla çalıştıkları örgüte sadık, örgütün amaçlarına ulaşabilmesi için yoğun çaba gösteren vefalı çalışanlara dönüşebilmektedirler. Bu tip çalışanlar, maddi zorunluluk sebebiyle değil, gerçekten istedikleri için örgütte kalmaya devam etmektedirler. Böylelikle bu durum çalışanlarıyla bütünleşmiş, güçlü bir örgütün oluşmasına zemin hazırlamaktadır (Ece ve Gültekin, 2018: 83). Çalışanlar aynı zamanda, iş ortaklarına güvendiklerinde kaynakları paylaşmaya ve çalışma arkadaşlarına yardım sağlamaya daha istekli olmaktadırlar. Bu nedenle, çalışanların çalışma arkadaşlarına duyduğu güvenin, çalışma arkadaşlarına yönelik örgütsel vatandaşlık davranışı ile olumlu yönde ilişkili olması beklenmektedir (Ong, 2013: 292).

Bu bilgiler ışığında, algılanan yönetici desteği ve algılanan çalışma arkadaşları desteği ile örgütsel vatandaşlık kavramlarının örgüt için olumlu etkiler oluşturabilecek önemli kavramlar olduğu söylenebilmektedir. Yazında bu üç değişkenin birbiriyle ilişkisini ele alan sınırlı sayıda çalışma olması dolayısıyla, algılanan yönetici desteği ve algılanan çalışma arkadaşları desteğinin örgütsel vatandaşlık davranışına etkisini belirlemek üzere çalışma kapsamında İzmir il Sağılı Müdürlüğü ve bağlı birimlerdeki 325 çalışan üzerinde bir araştırma gerçekleştirilmiştir. Araştırma sonucunda elde edilen bulgulara göre, algılanan yönetici desteği ile algılanan çalışma arkadaşları desteğinin, örgütsel vatandaşlık davranışı üzerinde etkili olduğu tespit edilmiştir. Elde edilen bulgular sonucunda, algılanan çalışma arkadaşları desteği ile örgütsel vatandaşıık davranışının pozitif ilişkili olduğu (Gençtürk, 2005; Chiaburu ve Harrison, 2008; Kopp, 2013) ve algılanan yönetici desteği ile örgütsel vatandaşlık davranışının pozitif ilişkili olduğu (Organ ve Ryan, 1995; Chen ve Chiu, 2008; Özdemir, 2010; Liu vd., 2011; Kopp, 2013; Wang, 2014; Sultana vd., 2016; Akram vd., 2018) yazındaki çalışmalarla paralellik göstermektedir.

Analiz sonuçlarına göre, algılanan yönetici desteği ve çalışma arkadaşları desteği ile ÖVD arasında anlamlı ve orta düzeyde pozitif ilişki olduğu görülmüştür. Çalışmada elde edilen bulgular ışığında, çalışanların yönetici desteği ve çalışma arkadaşı desteği algılarının çalışanların örgütsel vatandaşlık davranışı kapsamına giren davranışlarda bulunmalarını etkilediği sonucuna ulaşılmaktadır. Değişkenler arasındaki ilişkinin yüksek düzeyde olabilmesi için örgütlere ve yöneticilere bazı görevler düşmektedir. Çalışma hayatının yoğun 
temposu içinde her zaman dikkat edilmese de çalışanların maddi ihtiyaçları kadar manevi ihtiyaçları da mutlaka gözetilmelidir. Bilgi toplumunun gereği olarak öğrenen örgütlerin sayısının artmasıyla beraber çalışanların daha da önem kazandığı günümüzde, örgütler çalışanlarına eskisinden daha fazla önem vermekte ve personel devir hızının yükselmemesi için çaba sarf etmektedir. Bu doğrultuda, çalışanların en çok vakit geçirdikleri kişiler olan çalışma arkadaşları ve yöneticileriyle ilgili düşünceleri önem kazanmaktadır. Yöneticilerin, örgüt için ortaya çıkarabileceği sonuçların farkında olarak, çalışma arkadaşlarının birbirlerine karşı pozitif tavır ortaya koyabilecekleri aşırı rekabetçi olmayan, çalışanların psikolojik olarak huzurlu olabilecekleri bir ortam oluşturmaları gerekmektedir. Yöneticilerin duygusal, maddi ve bilgisel açıdan çalışanlarını desteklemesi, çalışanların örgütsel vatandaşlık davranışlarında bulunmalarını artırıcı rol oynayacaktır.

Çalışma kapsamında, yönetici desteği ve çalışma arkadaşı desteğinin örgütsel vatandaşlık davranışı alt boyutlarına olan etkisi de araştırılmıştır. Analizler neticesinde, bazı alt boyutlarla ilgili sonuçlar anlamlı çıkmamış, bu nedenle ilgili hipotezler kabul edilmemiştir. Örneğin; algılanan çalışma arkadaşları desteğinin örgütsel vatandaşlık davranışının nezaket boyutu üzerinde pozitif yönlü etkisi var iken algılanan yönetici desteğinin örgütsel vatandaşlık davranışının nezaket boyutu üzerinde etkisi bulunamamıştır. Bunun nedeni ise çalışanların örgütsel vatandaşık davranışı boyutlarından bazılarını yönetici desteğinin, bazı boyutlarını ise çalışma arkadaşları desteğinin daha çok etkilediğini düşünmesi olabilir.

Araştırma belirli bir örneklemle sınırlı olduğundan, araştırma sonuçları genellenememektedir. Çalışmada dördüncü faktör olan vicdanlılık ve centilmenlik 2 maddeden oluşmaktadır. Bir faktörün oluşabilmesi için en az üç madde gereklidir. Ancak bazı çalışmalarda bu durum söz konusu olduğu için (Eisinga vd., 2013) çalışmanın sınırılığı olarak belirtilebilmektedir. Bir diğer sınırlıık ise çalışmanın sadece bir ildeki kurum çalışanlarını kapsaması ve kamu sektöründe yapılmasıdır.

Araştırma verilerinin kesitsel bir nitelik taşıması, diğer bir ifadeyle verilerin, katılımcılardan bir defada elde edilmesi araştırmanın bir kısıtı olarak değerlendirilebilir. Bu kısıtın giderilmesi adına ilerleyen dönemlerde bu konular üzerinde çalışacak araştırmacılara boylamsal araştırmalar yapmaları önerilebilir. Ayrıca gelecekte yapılacak araştırmalarda, çalışanlara destek olma konusunda rol oynayabileceği düşünülerek yöneticilik ve liderlik tarzı ile kişilik tarzlarının, araştırma değişkenleriyle ilişkilendirilerek ele alınması önerilebilir. Yine gelecek çalışmalarda, aynı sektör ya da farklı sektörlerdeki çalışanların örneklem seçilmesi durumunda örgütsel vatandaşlık davranışı ile algılanan yönetici desteği ve algılanan çalışma arkadaşları desteği kavramları arasındaki ilişkinin sonuçları karşılaştırılabilir hale gelecektir.

\section{Beyan ve Açıklamalar (Declarations and Disclosures)}

Yazarların Etik Sorumlulukları (Ethical Responsibilities of Authors): Bu çalışmanın yazarları, araştırma ve yayın etiği ilkelerine uyduklarını kabul etmektedirler.

Etik Kurul Onayı (Ethical Approval): Araştırma kapsamındaki verilerin toplanması amacıyla Dokuz Eylül Üniversitesi Sosyal ve Beşeri Bilimler Araştırma ve Yayın Etik Kurulu'ndan 12.12.2019 tarihi itibariyle etik kurul izni alınmıştır.

Çıkar Çatışması (Conflicts of Interest): Yazarlar tarafından herhangi bir çıkar çatışması beyan edilmemiş̧ir.

Finansal Destek (Funding): Yazarlar, çalışmanın hazırlanması ve/veya yayınlanması sürecinde herhangi bir finansal destek almamışlardır.

Yazar Katkı Oranı (Author Contributions): Yazarlar, çalışmaya olan katkılarını şu şekilde beyan etmişlerdir: Kavramlaştırma ve çalışma dizaynı, Y. Tenteriz ve G. Tozkoparan; verilerin toplanması, Y. Tenteriz; verilerin analizi ve sonuçların yorumlanması, Y. Tenteriz ve G. Tozkoparan; çalışmanın ilk/taslak halinin yazılması, Y. Tenteriz; çalışmanın gözden geçirilmesi ve düzenlenmesi/düzeltilmesi, Y. Tenteriz ve G. Tozkoparan. Çalışmanın ilk ve son hali tüm yazarlar tarafından okunmuş ve onaylanmış olup, yazarlar çalışmalarıyla ilgili sorumluluğu kabul etmektedirler.

intihal Denetimi (Plagiarism Checking): Bu çalışma, intihal tarama programı kullanılarak intihal taramasından geçirilmiştir.

(*) ilave Açıkıama (Additional Disclosure): Bu çalışma, Yıldız Tenteriz'in Doç. Dr. Güler Tozkoparan danışmanlığında tamamlanmış olan “Algılanan Yönetici ve Çalışma Arkadaşları Desteğinin Örgütsel Vatandaşlık Davranışına Etkisi” başıkı yüksek lisans tezinden üretilmiştir. 


\section{Teşekkür}

Makalemizin değerlendirme sürecine zaman ve emek harcayarak değerli katkılarını sunan hakemlerimize teşekkürlerimizi sunarız.

\section{Kaynaklar}

Ackfeldt, A. L., \& Coote, L. V. (2005). A study of organizational citizenship behaviors in a retail setting. Journal of Business Research, 58, 151-159.

Akmaz, A., \& Erbaşı, A. (2017). Psikolojik kontrat ile örgütsel bağlılık ve örgütsel güven ilişkisi: Mersin ilindeki 4 ve 5 yıldızlı otel işletmelerinde bir uygulama. Bolu Abant İzet Baysal Üniversitesi Sosyal Bilimler Enstitüsü Dergisi, 17(4), 125-154.

Akram, A., Kamran, M., Iqbal, M. S., Habibah, U., \& Ishaq, M. A. (2018). The impact of supervisory justice and perceived supervisor support on organizational citizenship behavior and commitment to supervisor: The mediating role of trust. Cogent Business and Management, 5, 1-17.

Aselage, J., \& Eisenberger, R. (2003). Perceived organizational support and psychological contracts: A theoretical integration. Journal of Organizational Behavior, 24, 491-509.

Babin, B. J., \& Boles, J. S. (1996). The effects of perceived coworker involvement and supervisor support on service provider role stress, performance and job satisfaction. Journal of Retailing, 72, 57-75.

Basım, H. N., \& Şeşen, H. (2006). Örgütsel vatandaşlık davranışı ölçeği uyarlama ve karşılaştırma çalışması. Ankara Üniversitesi SBF Dergisi, 61(4), 83-101.

Bolino, M. C. (1999). Citizenship and impression management: Good soldiers or good actors? Academy of Management Review, 24(1), 82-98.

Büyüköztürk, Ş. (2002). Faktör analizi: Temel kavramlar ve ölçek geliştirmede kullanımı. Kuram ve Uygulamalarda Eğitim Yönetimi (32), 470-483.

Büyüköztürk, Ş. (2008). Sosyal bilimler için veri analizi el kitabı: İstatistik, araştırma deseni SPSS uygulamaları ve yorum. Ankara: Pegem Akademi.

Chen, C. C., \& Chiu, S. F. (2008). An integrative model linking supervisor support and organizational citizenship behavior. Journal of Business and Psychology, 23(1-2), 1-10.

Chiaburu, D. S., \& Harrison, D. A. (2008). Do peers make the place? Conceptual synthesis and meta-analysis of coworker effects on perceptions, attitudes, ocbs, and performance. Journal of Applied Psychology, 93(5), 1082-1103.

Çetin, M. Ö. (2004). Örgütsel vatandaşlık davranışı. Ankara: Nobel Yayın.

Ece, S., \& Gültekin, S. (2018). Yönetici desteği ve örgütsel bağlılık: Kamu sektöründe bir uygulama. Akademik Bakış Dergisi, 66, 82-93.

Eisenberger, R., Stinglhamber, F., Vandenberghe, C., Sucharski, I. L., \& Rhoades, L. (2002). Perceived supervisor support: Contributions to perceived organizational support and employee retention. Journal of Applied Psychology, 87(3), 565-573.

Eisinga, R., te Grotenhuis, M., \& Pelzer, B. (2013). The reliability of a two-item scale: Pearson, Cronbach, or SpearmanBrown? International Journal of Public Health, 58(4), 637-642.

Emhan, E., Mengenci, C., Taşdöven, H., \& Garayev, V. (2014). Yapısal eşitlik modeli kullanılarak iş memnuniyeti, yönetici desteği ve tükenmişlik kavramları arasındaki ilişkilerin analizi: Bankacılık sektöründe bir uygulama. Selçuk Üniversitesi Iktisadi ve Idari Bilimler Fakültesi Sosyal ve Ekonomik Araştırmalar Dergisi, 27, 75-96.

Ertürk, E. (2014). Sosyal mübadele teorisi bağlamında güç mesafesi ve örgütsel adalet algılamalarının örgütsel vatandaşlık davranışı üzerindeki etkisi. Selçuk Üniversitesi Sosyal Bilimler Enstitüsü, Doktora Tezi, Konya.

Gant, L. M., Nagda, B. A., Brabson, H. V. Jayaratne, S., Chess, W. A., \& Singh, A. (1993). Effects of undermining on African American workers' perceptions of coworker and supervisory relationships and psychological well-being. Social Work, 38, 158-164.

Gençtürk, O. C. (2005). Algılanan sosyal desteğin örgütsel vatandaşlık davranışı üzerine etkisi- bir vaka çalışması. İstanbul Üniversitesi Sosyal Bilimler Enstitüsü, Yayınlanmamış Yüksek Lisans Tezi, İstanbul.

Gillen, M., Baltz, D., Gassel, M., Kirsch, L., \& Vaccaro, D. (2002). Perceived safety, climate, job demands, and coworker support among union and nonunion injured construction workers. Journal of Safety Research, 33, 33-51. 
Algılanan Yönetici Desteği ve Algılanan Çalışma Arkadaşları Desteğinin Örgütsel Vatandaşlık Davranışı Üzerine Etkisi

Giray, M. D., \& Şahin, D. N. (2012). Algılanan örgütsel, yönetici ve çalışma arkadaşları desteği ölçekleri: Geçerlik ve güvenirlik çalışması. Türk Psikoloji Yazıları, 15(30), 1-9.

Giray, D. M. (2013). İş yeri desteği: örgüt, yönetici ve çalışma arkadaşları desteğine genel bir bakış. "İş, Güç" Endüstri ilişkileri ve Insan Kaynakları Dergisi, 15(3), 65-81.

Guchait, P., Cho, S., \& Meurs, J. A. (2015). Psychological contracts, perceived organizational and supervisor support: Investigating the impact on intent to leave among hospitality employees in India. Journal of Human Resources in Hospitality and Tourism, 14(3), 290-315.

Hair, J. F., Black, W. C., Babin, B. J., Anderson, R. E., \& Tatham, R. L. (2013). Multivariate data analysis. Pearson Education Limited.

Jiang, J. J., \& Kline, G. (2000). Supervisor support and career anchor impact on the career satisfaction of the entry-level information systems professional. Journal of Management Information Systems, 16, 219-240.

Karaman, A., \& Aylan, S. (2012). Örgütsel vatandaşlık. Kahramanmaraş Sütçü Imam Üniversitesi İktisadi ve Idari Bilimler Fakültesi Dergisi, 2(1),35-48.

Karasek, R. A., Triantis, K. P., \& Chaudhry, S. S. (1982). Coworker and supervisor support as moderators of associations between task characteristics and mental strain. Journal of Occupational Behavior, 3, 181-200.

Kopp, L. R. (2013). The effects of perceived supervisor support work-life support on employee work-life balance, job satisfaction, organizational commitment, and organizational citizenship behavior. University of Wisconsin-Stout, Unpublished Master Thesis.

Lian, L. K., \& Tui, L. G. (2012). Leadership styles and organizational citizenship behavior: The mediating effect of subordinates' competence and downward influence tactics. Journal of Applied Business and Economics, 13(2), 59-96.

Liu, J., Cho, S., \& Seo, W. (2011). OCB: Investigating the impact of psychological contract and perceived supervisor support in the hospitality industry in South Korea. Houston, Texas, USA.

Liden, R. C. \& Maslyn, J. M. (1998). Multidimensionality of leader-member exchange: An empirical assessment through scale development. Journal of Management, 1,43-72.

Mossholder, K. W., Settoon, R. P., \& Henagan, S. C. (2005). A relational perspective on turnover: Examining structural, attitudinal, and behavioral predictors. Academy of Management Journal, 48(4), 607-618.

Netemeyer, R. G., Boles, J. S., McKee, D. O., \& McMurrian, R. (1997). An investigation into the antecedents of organizational citizenship behaviors in a personel selling context. Journal of Marketing, 61, 85-98.

Ong, L. D. (2013). Workplace friendship, trust in coworkers and employees' OCB. University of Malaya, Kuala Lumpur, Malaysia.

Organ, D. W. (1988). Organizational citizenship behavior: The good soldier syndrome. Lexington. MA: Lexington.

Organ, D. W., \& Ryan, K. (1995). A meta-analytic review of attitudinal and dispositional predictors of organizational citizenship behavior. Personnel Psychology, 48, 775-802.

Organ, D. W. (1997). Organizational citizenship behavior: It's Construct clean-up time. Human Performance, 10(2), 8597.

Özdemir, A. (2010). İlköğretim okullarında algılanan yönetici desteğinin ve bireycilik-ortaklaşa davranışçılığın örgütsel vatandaşlık davranışı ile ilişkisi. Kuram ve Uygulamada Eğitim Yönetimi, 16(1), 93-112.

Özdevecioğlu, M. (2003). Örgütsel vatandaşlık davranışı ile üniversite öğrencilerinin bazı demografik özellikleri ve akademik başarıları arasındaki ilişkilerin belirlenmesine yönelik bir araştırma. Erciyes Üniversitesi iktisadi ve Idari Bilimler Fakültesi Dergisi, 20, 117-135.

Podsakoff, P. M., \& MacKenzie, S. B. (1997). Impact of organizational citizenship behavior on organizational performance: A review and suggestion for future research. Human Performance, 10(2), 133-151.

Podsakoff, P. M., MacKenzie, S. B., Paine, J. B., \& Bachrach, D. G. (2000). Organizational citizenship behaviors: A critical review of the theoretical and empirical literature and suggestions for future research. Journal of Management, 26(3), 513-563.

Raabe, B., \& Beehr, T. A. (2003). Formal mentoring versus supervisor and coworker relationships: Differences in perceptions and impact. Journal of Organizational Behavior, 24, 271-293.

Rhoades, L., \& Eisenberger, R. (2002). Perceived organizational support: A review of the literature. Journal of Applied Psychology, 87(4), 698-714.

Sabuncuoğlu, Z., \& Tüz, M. V. (2005). Örgütsel psikoloji. Bursa: Alfa Aktüel Basım. 
Susskind, A. M., Kacmar, K. M., \& Borchgrevink, C. P. (2003). Customer service providers' attitudes relating to customer service and customer satisfaction in the customer-server exchange. Journal of Applied Psychology, 88(1), 179187.

Sultana, N., Rabie, O., Farooq, M., \& Amjad, A. (2016). The impact of perceived supervisor support on OCB: The moderating effect of introversion. The Lahore Journal of Business, 5(1), 37-58.

Tabachnick, B. G., \& Fidell, L. S. (2013). Using multivariate statistics (Sixth ed.). Pearson, Boston.

Turnley, W. H., Bolino, M. C., Lester, S. W., \& Bloodgood, J. M. (2003). The impact of psychological contract fulfillment on the performance of in-role and organizational citizenship behaviors. Journal of Management, 29(2), 187-206.

VanYperen, N. W., Van den Berg, A. E., \& Willering, M. C. (1999). Towards a better understanding of the link between participation in decision-making and organizational citizenship behaviour: A multilevel analysis. Journal of Occupational and Organizational Psychology, 72, 377-392.

Vey, M. A., \& Campbell, J. P. (2004). In.role or extra. Role organization al citizenship behavior: Which are we measuring? Human Performance, 17(1), 119-135.

Wang, Z. (2014). Perceived supervisor support and organizational citizenship behavior: The role of organizational commitment. International Journal of Business and Social Science, 5(1), 210-214.

Williams, S., \& Shiaw, W. T. (1999). Mood and organizational citizenship behavior: The effects of positive affect on employee OCB intentions. The Journal of Psychology, 133(6), 656-668.

Yoon, J., \& Lim, J. C. (1999). Organizational support in the workplace: The case of Korean hospital employees. Human Relations, 52(7), 923-945.

Yüksel, i. (2006). Örgütsel destek algısı ve belirleyicilerinin işten ayrılma eğilimi ile ilişkisi. İşletme Fakültesi Dergisi, 35(1), 7-32.

Zincirkıran, M., Yalçınsoy, A., \& Işık, M. (2016). Yönetici desteği ile iş memnuniyeti arasındaki ilişkinin incelenmesi. 2nd International Congress on Economics and Business, 976-983. 
This Page Intentionally Left Blank 